\title{
UNA BODA EN LA PEQUEÑA NOBLEZA ALICANTINA DEL SETECIENTOS: LOS SOLER DE CORNELLÁ Y LOS JUAN A TRAVÉS DE SU CORRESPONDENCIA
}

\author{
Rosario DIE MACULET \\ Armando ALBEROLA ROMÁ
}

Universidad de Alicante

Resulta evidente el interés que despierta en la actualidad entre los historiadores el estudio de las cuestiones relacionadas con la familia y su entorno. Ese interés ha comenzado a desbordar el marco estrictamente demográfico para penetrar en el análisis de aspectos sociales, entendiendo el término social en su sentido más extenso. De ahí que, tanto la vida cotidiana como el marco jurídico en el que se establece el contrato matrimonial -por poner dos ejemplos suficientemente diferenciados--, son objeto de la atención de los investigadores, junto a otras muchas facetas de la vida familiar.

La abundancia y calidad de publicaciones recientes referidas a estos temas ${ }^{1}$ permiten considerar que aquella reflexión, formulada hace algo más de un lustro y según la cual nos encontrábamos ante una historia "por hacer"2, debe empezar a matizarse; pese a que resten parcelas escasamente estudiadas por el momento, como las referidas a los sentimientos o a la economía doméstica ${ }^{3}$.

Los grupos familiares han sido contemplados desde la perspectiva de sus actividades económicas, contextualizándolas adecuadamente en la sociedad en la que se incardinan ${ }^{4}$. Se analizan los vínculos establecidos en el ámbito urbano entre diferentes familias y cuyo objeto era conformar poderosas oligarquías dirigidas hacia el control de la vida política Iocal ${ }^{5}$. Asimismo, se estudia el papel que la familia tiene como transmisora de propiedades, al igual que la función desempeñada por la sociedad matrimonia 6 . El empleo del matrimonio como estrategia para reunir importantes fortunas era propio de la nobleza en sus diferentes categorías ${ }^{7}$, y es a este aspecto, referido al ámbito alicantino y a la pequeña nobleza urbana en él asentada, al que dedicaremos las páginas del presente trabajo. 
El hallazgo, entre los documentos que custodia el Archivo privado de la marquesa del Bosch en Alicante, de un legajo de correspondencia relativa a los preparativos del matrimonio que contrajeron en 1763 el caballero ilicitano Francisco Soler de Cornellá y Ros de Ursinos y Rafaela Juan Ximénez de Urrea ${ }^{8}$, nos brinda la oportunidad de descender a un grado de detalle poco habitual en estos casos y ofrecer, en consecuencia, un ejemplo concreto de lo que podían ser estos comportamientos en el seno de la pequeña nobleza del antiguo reino valenciano?

Pero si interesante puede resultar el contenido de la correspondencia, no lo es menos el estudio y análisis del ámbito familiar de los contrayentes. Las intrincadas alianzas matrimoniales concertadas en la época, dirigidas a mantener a sus miembros dentro del rango que tenían por su nacimiento, condujo a unos elevados niveles de endogamia entre las familias más relevantes de aquella sociedad. La causa de que las ramas genealógicas se trenzaran de manera semejante a la de los hilos de un encaje radica en la necesidad de mantener los patrimonios familiares reunidos, y a ser posible aumentados, como único medio para poder asegurar el acomodado nivel de vida en el que se desenvolvían.

La tardanza en contraer matrimonio por parte del primogénito varón, así como la notable e incluso a veces extraordinaria diferencia de edad entre los contrayentes no resultan extrañas y es una tendencia puesta de manifiesto por los historiadores 10 . La raíz de este hecho ha de buscarse en la total sujeción de los hijos a la autoridad paterna. El padre disfrutaba y administraba los bienes familiares, incluso las legítimas maternas, por lo que los hijos no podían disponer libremente de su patrimonio hasta que se producía la muerte de aquél. Ello conllevaba una dependencia económica absoluta de los hijos respeto de su progenitor y determinaba en gran medida la tardanza de aquéllos en casarse y fundar una familia.

En consecuencia, no parece superfluo realizar una breve reseña del círculo familiar en el que vivieron los dos principales personajes de esta "función"11, cuyo ensayo se prolongó durante varios meses y que se celebró en Alicante el día 18 de diciembre de $1763^{12}$.

\section{LOS SOLER DE CORNELLÁ}

La familia Soler de Cornellá está bien documentada y estudiada. Varios son los trabajos que se han escrito analizando tanto la figura de alguno de sus miembros como la trayectoria de la familia en sí y su influencia económica o política en la ciudad de Elchel3.

Dentro de la escala social vigente en el siglo XVIII podemos situar a los Soler entre la nobleza media avecindada en provincias, caballeros y ricos propietarios de tierras que intentarán perpetuar su fortuna y apellidos mediante mayorazgos y vínculos establecidos a favor de sus primogénitos. Fieles al estereotipo de la época, procurarán encauzar al resto de sus miembros hacia el ejército, la iglesia o el malrimonio contraído con sujetos integrados dentro de su círculo, como medio para mantener el elevado tono de vida acorde con su ilustre linaje. 
Francisco Soler de Cornellá, cuya alianza matrimonial constituye el núcleo del presente trabajo, había nacido en Elche el día 6 de octubre de $1726^{14}$. Hijo de Don Leonardo Soler de Cornellá y Vaíllo de Llanos y de Doña Vicenta Ros de Ursinos y Barberá, tuvo cinco hermanos llamados Josefa, Dionisio, Pedro, Leonardo y Vicente.

De todos ellos fue sin duda Leonardo la figura más sobresaliente. Nacido el 10 de abril de 1736, siguió la carrera eclesiástica, llegando a ser un eminente orador y autor de reputados trabajos relativos al arte de la predicación. En su doble faceta de miembro de una influyente familia de la nobleza ilicitana y, a la vez, por su condición de religioso, con una amplia cultura humanística, su obra resulta clave en la reforma de la predicación y la oratoria sagrada durante el siglo XVIIII5. En 1763, año al que se circunscribe el presente trabajo, Leonardo era presbítero de la Iglesia del Salvador de Elche, de donde pasó pocos meses después a la Iglesia parroquial de la villa de Almoradí. Cuando murió, el 27 de abril de 1796, era canónigo magistral de la Catedral de Orihuela.

Dionisio, típico segundón, siguió la carrera militar adscribiéndose a un cuerpo netamente nobiliario como eran los Guardias de Corps ${ }^{16}$. A finales de 1762 y durante 1763 , formando parte de la Compañía Italiana de Su Majestad, se encontraba destacado en la ciudad de Mérida por exigencias de la guerra que se desarrollaba entre España e Inglaterra ${ }^{17}$.

Pedro había casado con Joaquina Llanzol en $1753^{18}$, mientras que Vicente, último de los hermanos, siguió otra trayectoria habitual en la familia, cual cra el ingreso en la Orden de San Juan de Malta ${ }^{19}$. En 1762 era caballero del Hábito de San Juan de Jerusalén y Alférez de Fragata de la Real Armada20.

Finalmente nada podemos decir de la única hermana, Josefa, salvo que contrajo matrimonio en 1746 con Francisco Martínez de la Raga ${ }^{21}$. Es posible que en las fechas estudiadas ya hubiera muerto. En el testamento de sus padres, redactado en 1740, Josefa ocupa el último lugar en la sucesión del vínculo que los testadores crean en cabeza del primogénito varón. En esta escritura, además, su madre establece sobre sus bienes una mejora de 400 libras a favor de la hija. Con posterioridad a csa fecha, ni en las demás escrituras notariales consultadas ni en las cartas se encuentra mención a ella.

Francisco, el primogénito varón y heredero del linaje, no tuvo una trayectoria personal destacada ni excepcional. Como uno más de los centenares de aristócratas de su época, herederos del patrimonio familiar, su vida se encauzó hacia la administración y aumento de su fortuna, con escaso éxito por cierto. Desempeñó asimismo diversos cargos públicos en la villa de Elche, de donde fue en varias ocasiones alcalde ordinario. Fue Abogado de los Reales Consejos, caballero maestrante de la Real Maestranza de Valencia y Familiar Numerario y Alguacil mayor del Santo Oficio de la Inquisición de Murcia en la villa de Elche ${ }^{22}$. Su anodina figura carecería para nosotros de especial interés si no fuera porque se ha conservado su correspondencia particular. 


\section{LA FAMILIA JUAN}

A la hora de buscar esposa, Francisco no se alejó mucho del ámbito familiar y su elección recayó en María Rafaela Juan Ximénez de Urrea, con cuya familia mantenían los Soler de Cornellá una estrecha amistad y complicados lazos de parentesco. Nicolás Juan Pascual del Pobil, padre de la novia, era hermano consanguíneo de Jorge, Margarita y Bernardo Juan Santacilia y éstos, a su vez, primos segundos de Francisco Soler.

Para situar correctamente a María Rafaela Juan dentro de su entorno familiar conviene hacer una sucinta referencia a sus antecesores más inmediatos, para lo cual basta remontarnos a su abuelo paterno.

Don Bernardo Juan Canicia, caballero de Alicante, contrajo matrimonio en dos ocasiones. En 1694 casó en primeras nupcias con su pariente doña Isabel Ana Pascual del Pobil y Gisbert ${ }^{23}$. De dicho matrimonio nacieron cinco hijos, llamados Francisca María, María Manuela, Antonio, Nicolás y Cipriano. Tras morir su esposa de sobreparto en octubre de 1709, contrajo segundas nupcias en 1711 con doña Violante Santacilia Soler. Ésta era viuda a su vez de don Pedro Ybarra Paravicino, con quien había tenido tres hijos llamados José Vicente, Teresa y Antonia Ybarra Santacilia ${ }^{24}$.

De la unión de Bernardo y Violante nacieron Jorge, el ilustre marino y científico; Margarita, quien andando el tiempo sería esposa de Ignacio Burgunyo Ruiz de Benitive; y un hijo póstumo, también llamado Bernardo, que vino al mundo tres meses después del fallecimiento de su padre.

La familia así formada por Bernardo Juan y Violante Santacilia constituye un perfecto ejemplo con el que podría ilustrarse un apartado de Derecho Civil relativo al parentesco. En ella podemos distinguir entre los hermanos de doble vínculo o germanos, hijos de los mismos progenitores, como es el caso de Jorge, Margarita y Bernardo Juan Santacilia; y los hermanos de vínculo sencillo o medio hermanos, con un solo progenitor común. Éstos se denominan consanguíneos, cuando tienen el padre en común y distinta la madre. En este supuesto se hallaban Jorge, Margarita y Bernardo Juan Santacilia respecto a Francisca, Manuela, Antonio, Nicolás y Cipriano Juan Pascual del Pobil. Cuando el progenitor común es la madre se llaman uterinos, como sucedía entre los repetidos Jorge, Margarita y Bernardo respecto a José Vicente, Teresa y Antonia Ybarra Santacilia. ${ }^{25}$ Finalmente, los hijos del primer matrimonio de Bernardo y los del primer matrimonio de Violante eran entre sí hermanastros.

No se debe confundir a los medio hermanos, ya sean consanguíneos o uterinos, con los hermanastros, pues éstos últimos son los hijos que uno de los cónyuges tiene, procedentes de una unión anterior, con respecto a los hijos que el otro cónyuge ha tenido a su vez con otra persona. Entre hermanos y medio hermanos el matrimonio está absolutamente prohibido, por constituir dicho grado de parentesco un impedimento de Derecho Natural, y como tal no dispensable. Los hermanastros, por el contrario, pueden casarse entre sí por no existir entre ellos ninguna clase de parentesco. 
Esta premisa es esencial para comprender un hecho que contribuyó a reforzar la unión entre los miembros de tan dispar familia. En 1730 Nicolás Juan Pascual del Pobil casó en primeras nupcias con su hermanastra Teresa Yvarra Santacilia, con quien tuvo al menos tres hijas: María Antonia, María Manuela e Isabel María ${ }^{26}$.

Habiendo enviudado a los pocos años de matrimonio, Nicolás Juan casó por segunda vez en Zaragoza con María Rita Ximénez de Urrea y Bagués, hija de los Condes de Berbedel. Fruto de este enlace fueron más de siete hijos, de los que al menos cuatro llegaron a la mayoría de edad: Francisco de Paula, quien ingresaría en las Reales Compañías de Guardias Marinas; María Rafaela, cuyo matrimonio con Francisco Soler de Cornellá centra el presente trabajo; María Francisca, casada en 1758 a los 14 años de edad con José Sannazar, Marqués de Arneva, un viudo que le sobrepasaba en 17 años; y María Luisa, quien casaría en 1776 con Federico Mendoza de Sotomayor 27.

De María Rafaela, nacida en Alicante en 1742, poco podemos añadir, salvo que contaba al casarse con 21 años, 16 menos que su prometido. Siendo menor de edad y mujer, lo extraño habría sido poseer mayores conocimientos acerca de su persona.

\section{LA FORTUNA DE FRANCISCO SOLER DE CORNELLÁ}

Francisco no se apresuró a contraer matrimonio, pues cuando lo hizo contaba 37 años de edad. Quizá no resulte descabellado pensar que ello pudo deberse a razones de índole económica, como podría evidenciar el hecho de que, como veremos más adelante, no entró en posesión de parte de sus bienes hasta la muerte de su padre, acaecida en noviembre de 1762.

Como primogénito, Francisco heredaría la mayor parte de los bienes familiares llegando a reunir, a lo largo de su vida, hasta cuatro vínculos de distinta procedencia. El grueso de su herencia estaba formado por el vínculo instituido por sus padres en su testamento fechado en $1740^{28}$, cuyo núcleo principal lo constituía la hacienda y olivares de Benicaixer con ocho hilos de agua, así como la casa solariega situada en la villa de Elche.

También heredó el vínculo fundado por su tío, el beneficiado Don Pedro Soler de Cornellá, en su testamento otorgado el 8 de mayo de 1757 ante el escribano Carlos Pasqual ${ }^{29}$. En dicha escritura el testador, tras efectuar diversos legados a sus restantes sobrinos varones, nombra como su heredero universal a Francisco Soler, a quien designa como sucesor en el mayorazgo que instituye sobre las siguientes propiedades:

- Una heredad situada en la partida de Asprillas, parte plantada de viña y otros árboles y parte de tierra blanca, que contaba así mismo con una casa habitación, cisternas de agua pluvial y salada y ermita ${ }^{30}$.

- Noventa y cinco tahúllas de olivar situadas en la partida del Palombar, anejas a la heredad de Asprillas.

- Una pieza de tierra blanca situada en la partida de Beniay ${ }^{31}$ y 80 tahúllas de olivar en la partida de Partidor. 
- Nueve hilos de agua inscritos en el Libro de la partición de las aguas de la villa de Elche y una almazara de tres prensas, que se comunicaba con la de su hermano don Leonardo y con la que compartía una misma zafa y rulo para la molienda de la aceituna.

Sin embargo, en 1763 y respecto a este mayorazgo, Francisco todavía habría de esperar más de 14 años para disfrutarlo puesto que su tío don Pedro Soler murió en fecha indeterminada que cabe situar entre los años 1777 y $1783^{32}$. Con el correr de los años aún ingresaron en su patrimonio dos vínculos más, a saber, el fundado por su primo José Soler de Cornellá y Martínez de la Raga sobre la Alquería de la Limera, en Valencia; y el instituído por su prima Vicenta March y Ros ${ }^{33}$.

Desconocemos la fecha en que se convino la alianza matrimonial entre Francisco y Rafaela pero un factor decisivo en la preparación y puesta en marcha de la ceremonia nupcial lo constituyó, como queda dicho, la muerte de don Leonardo Soler de Cornellá, padre de Francisco, acaecida el 4 de noviembre de $1762^{34}$.

A los 78 años de edad es indudable que don Leonardo, antes de morir, intentó dejar arreglados sus asuntos con vistas a asegurar correctamente el reparto de sus bienes entre los cinco hijos varones. A tal fin, el 17 de septiembre de 1762, solicitó ante el Corregidor de la villa de Onteniente el justiprecio judicial de varias fincas que poseía en dicho término; diligencias que finalizaron el 9 de octubre de ese mismo año, siéndole notificadas por auto a su procurador en la misma fecha ${ }^{35}$.

Apenas once días después, postrado en cama y tan enfermo que ni siquiera pudo firmar, otorgó su último codicilo por el que anulaba lo dispuesto en otro anterior, de 10 de abril de 1751. En esa su postrera disposición modificaba la asignación de bienes que tenía realizada a favor de su hijo Vicente, legaba a sus hijos Leonardo, Pedro y Dionisio determinados bienes en pago de sus legítimas y, finalmente, agregaba los muebles y los objetos de plata que poseía en su casa de Elche al vínculo que había fundado en su testamento de 1740 a favor de su primogénito, Francisco ${ }^{36}$.

Murió don Leonardo dos semanas después, y debido a la complejidad de la herencia ${ }^{37}$, las operaciones sucesorias no concluyeron hasta el seis de febrero de 1763 con la elevación a escritura pública del Convenio, Divición y Partición de la herencia del difunto don Leonardo Soler ottorgada entre sus hijos ${ }^{38}$. En este documento los hermanos Soler de Cornellá, excepto Josefa, procedían en realidad a inventariar y repartir los bienes integrantes de tres distintas herencias: la de su padre, don Leonardo Soler, fallecido unos meses antes; la de su madre, y esposa del anterior, doña Vicenta Ros Barberá, muerta en 1740; y la de la madre de ésta última y abuela de los otorgantes, doña Lucía Anna Barberá Despuch, que falleció con posterioridad a su hija ${ }^{39}$.

Estas tres herencias se hallaban a la sazón indivisas. Para proceder al inventario y división de los bienes recayentes en ellas, el difunto don Leonardo había designado a su hermano don Pedro (a quien los herederos relevaron de dicho encargo debido a su avanzada edad y precario estado de salud) y a su sobrino don Bernardo Juan, 
quien por su condición de abogado era la persona más indicada para ello. Éste, además, actuaba como curador de Vicente Soler, el único de los hermanos que aún no había cumplido los veinticinco años. La tarea de Bernardo Juan consistió en efectuar el inventario general de todos los bienes disfrutados y administrados por el difunto, determinar a qué concreta herencia pertenecían y poder de ese modo formar la hijuela de cada heredero según su participación en cada una de ellas.

La herencia de doña Vicenta Ros estaba constituída por la suma de 1.000 libras, donadas por su esposo a título de arras, y otras 5.000 libras, a que ascendía el valor de los bienes que aportó como dote cuando contrajo matrimonio. Éstos consistieron en diferentes propiedades situadas en la villa de Onteniente, así como varios capitales de censos en dicha villa y en la de Monóvar40.

El cuerpo de bienes pertenecientes a la herencia de don Leonardo estaba constituido, además de por los muebles, joyas y semovientes prolijamente descritos en el inventario, por la importante hacienda situada en la partida de Benicaxier compuesta por 236 tahúllas de tierra plantadas de olivos, higueras y otros árboles, una casa habitación y 8 hilos de agua para el riego de dicha heredad. Poseía además don Leonardo una almazara de tres bigas y la casa solariega de los Soler, sitas ambas propiedades en la villa de Elche. Finalmente, se contaban tambien entre sus posesiones 280 tahúllas de tierra almarjal sitas en la partida de la Balsa Larguera de Elche, así como los bienes a que hemos hecho mención antes, situados en la villa de Onteniente y aportados por doña Vicenta Ros como dote.

En las referidas herencias paterna y materna, el primogénito Francisco resultaba mejorado en el tercio y quinto de todos los bienes, asignándose para pago de esta mejora la hacienda con su casa, tierras y olivares sita en la partida de Benicaxier, ocho hilos de agua para el riego de dicha hacienda, y además la casa habitación de la familia, situada en la villa de Elche.

Finalmente, la herencia perteneciente a la abuela materna consistía en cinco bancales de tierra huerta sitos en la partida del Plá, de la villa de Onteniente; una pieza de tierra de secano sita en el barranco de Agres, de dicha villa; 240 libras de un crédito que la difunta ostentaba contra los herederos de Francisco Berenguer; y 53 libras 5 sueldos del importe de las alhajas de plata que correspondieron a los hermanos Soler en la división de la herencia de su abuela. Todos estos bienes ascendían a un total de 1.856 libras, 8 sueldos y 6 dineros que debían repartirse entre los cinco hermanos por igual al no haber mejorado la difunta a ninguno de ellos.

Concluídas las operaciones particionales correspondieron a Francisco, en pago de sus legítimas y mejoras, todos los bienes expresamente asignados a él y algunos otros por un importe global de 11.874 libras. Muy inferior resultaba la parte correspondiente a sus hermanos: Ia hijuela de Dionisio ascendía a 2.524 libras; a Pedro correspondían 2.452 libras; Leonardo y Vicente, por último, habrían de recibir cada uno bienes por valor de 2.443 libras.

Una vez asegurada la estabilidad patrimonial, el objetivo del primogénito había de ser formar una familia. 


\section{EL MATRIMONIO DE FRANCISCO SOLER Y RAFAELA JUAN A TRAVÉS DE LA CORRESPONDENCIA}

Como ya queda dicho, el 18 de diciembre de 1763 contrajeron matrimonio, en la Iglesia Colegial de San Nicolás de Alicante, Francisco Soler y Rafaela Juan. EI interés que para nosotros tiene este concreto enlace radica principalmente en el hecho de que, en el Archivo privado de la Marquesa del Bosch, se ha conservado la correspondencia relativa a los preparativos de dicho matrimonio.

El legajo estudiado se compone de 48 cartas recibidas por Nicolás Juan y su esposa María Rita, durante los meses que precedieron a la boda de su hija Rafaela. Es lógico pensar, por ello, que fuera el propio Nicolás quien las reunió y guardó, posibilitando su conservación hasta nuestros días. Aproximadamente la mitad de estas cartas fueron escritas por Francisco Soler de Cornellá y en ellas, además de informar a su futuro suegro sobre la marcha de los preparativos de la boda, solicita instrucciones acerca del modo en que debían ir efectuándose aquéllos. Las cartas restantes son felicitaciones enviadas por familiares y amigos. La lectura de estas misivas, dirigidas por Francisco Soler a quien había de ser su suegro y a la propia novia en los meses previos al enlace, revive ante nuestros ojos todo el cúmulo de preparativos, impaciencias, anécdotas e incluso recelos, pueriles o no, que un acontecimiento de esa magnitud origina en la rutina de la vida cotidiana; nos permite, además, conocer las circunstancias que rodearon esta boda celebrada hace más de doscientos años entre miembros de dos acreditadas familias de la pequeña nobleza ilicitana y alicantina.

Pese a la falta de correspondencia cruzada, dado que no disponemos de las cartas escritas a su vez por Nicolás Juan -salvo algún borrador-, resulta fácil seguir el ritmo de los acontecimientos debido al hecho de que, junto a las cartas de Francisco y en estrecha relación con ellas, se encuentran varias misivas de los hermanos Bernardo y Jorge Juan Santacilia, así como las de numerosos familiares y amigos a quienes se comunicó la proyectada unión. Se conserva incluso un minúsculo borrador en el que Nicolás Juan enumeró la lista de personas a quienes debía "dar la cuenta" de la boda de su hija y cuyos nombres fue tachando conforme lo iba efectuando.

Estos dos distintos bloques de cartas nos permiten conocer y analizar el acontecimiento nupcial en dos planos diferentes pero inseparables. Por un lado el aspecto privado y doméstico de la preparación de la boda, circunscrito a sus protagonistas principales y a la familia inmediata, pudiendo encuadrarse aquí el grupo de cartas escritas por Francisco Soler y distintos miembros de la familia Juan.

Por otro lado, el aspecto público, social e incluso frívolo, tan importante a la hora de decidir la conveniencia o no de determinada unión, su aceptación o rechazo por un círculo más amplio de personas, fuera ya del estricto ámbito familiar; se incluirían aquí las cartas enviadas por los amigos y parientes en grado más lejano. 


\section{LOS PREPARATIVOS NUPCIALES}

Fechada la primera carta de Franciso Soler en abril de 1763 y siendo la última del 10 de diciembre de ese mismo año, ocho días antes de la boda, el período abarcado en ellas es lo suficientemente amplio como para darnos a conocer los preparativos completos del enlace, ofreciéndonos una visión directa y real de situaciones y aspectos que por su carácter básicamente cotidiano y doméstico no pueden recogerse nunca en otro tipo de fuentes más abundantes, como puedan ser los documentos administrativos, las escrituras notariales o las inscripciones parroquiales.

\section{Un trámite importante: la pensión de viudedad}

Comienza Francisco la primera de sus cartas, escrita como queda dicho a mediados de abril, con la noticia de haber concluído de modo satisfactorio el reparto de la herencia paterna entre todos los hermanos. Claramente expone cómo la preparación de su enlace había quedado relegada a un segundo plano, en tanto no estuvieran absolutamente terminadas todas las operaciones sucesorias pendientes:

“...Habiendose orillado todas las dependiencias de casa entre los hermanos con la mayor armonia, y quedado arreglada la division y particion de todos los bienes con reciproca satisfacsion de los hermanos y mia, y con estabilidad firme para que en lo sucsesivo no pueda haver la menor alterasion, inmediatamente procure arreglar todas las Diligencias judiciales presisas para la Consecusion de la convenida viudedad à favor de Mi Sra. Da. Rafaela, las que en efecto en este dia tengo remitidas al Agente para su presentasion en el Consejo, y escrito a Jorge para que estando a la vista al tiempo de la terminasion procure sea esta con las mayores ventajas..." 4 I.

Francisco, actuando indudablemente de acuerdo con Nicolás Juan, había solicitado al Consejo de Castilla autorización para constituir una pensión de viudedad sobre las rentas de sus vínculos a favor de la que había de ser su esposa. Debido a los estrechos lazos familiares que ligaban a ambos con Jorge Juan Santacilia, primo segundo de Francisco y medio hermano a su vez de Nicolás; y atendiendo también a la notable influencia que aquél podía ejercer en determinadas esferas oficiales de la villa de Madrid, no resulta extraño que el prestigioso marino fuera el encargado de defender esta petición ante la Junta de Viudedades.

Mientras duró la tramitación de dicho asunto, Francisco no se atrevió a ausentarse de Elche por si desde Madrid le reclamaban algún papel o diligencia necesarios para la marcha del expediente. Así, pese a que tenía previsto marchar a Valencia durante el mes de mayo para comprar vestidos y adornos para la casa, sus planes sufrieron un tremendo retraso dado que no consiguió la tan ansiada Cédula Real hasta principios de agosto:

“...participo a Vmd. como en este Correo me ha remitido el Agente de Madrid la cedula real para la viudedad de mi Sra. Da. Rafaela, dandome el Rey facultad para que sobre los bienes de mis vinculos pueda señalar á esta Señora la cantidad de ciento y ochenta y nueve libras, sin enbargo de que lo que se pidio fueron doscientas libras como quedamos acordados, yo hubiera querido que hubieran sido mucho mas, y para cllo hise quanto pude poniendo este negocio en manos y direcsion de Jorge, que es el que lo ha dirijido, quien no dudo havra hecho su dever..."42. 
No obstante la pequeña rebaja sufrida, se felicita a continuación por el resultado obtenido ya que, habiéndose pedido la pensión de viudedad de Rafaela al mismo tiempo que la de su hermana consanguínea Manuela ${ }^{43}$, a ésta se le concedieron únicamente 200 libras pese a que las rentas de los vínculos de su esposo, Juan Roca de Togores, duplicaban las de Francisco Soler.

\section{Los regalos y el anuncio "oficial" del enlace}

Es interesante destacar la frecuente mención que en el epistolario se hace a la ayuda, mediación o consejo que proporcionaba Jorge Juan. Éste, debido a su trayectoria profesional y a su influyente posición, era el valedor indiscutible de la familia, que acostumbraba a encomendarle la gestión de cuantos asuntos podían requerir un especial seguimiento o vigilancia estrecha en la Corte para su solución satisfactoria.

Pero la ayuda de Jorge Juan no se limitaba al ámbito que pudiéramos llamar administrativo, sino que descendía a detalles no por domésticos menos importantes. Residiendo en Madrid estaba en disposición de acudir a los mejores comerciantes y artesanos y conseguir determinados artículos cuya adquisición no debía ser fácil en Alicante o en Elche. Por esta razón, Francisco le encomendó la compra de un aderezo con el que pensaba obsequiar a su prometida, así como un tocador de charol conpuesto de espejo dos cofresitos cajas y otros Miriñaques presisos de damas ${ }^{44}$. Cumplido el encargo, Jorge se lo envió añadiendo de su parte una piocha, como regalo suyo a la novia:

"...Jorge me inbio estos dias el adereso de mi Sra. Da. Rafaela, con una piocha muy linda conque el de su parte regala á esta Señora, a quien dira Vmd puede disponer de estas Alhajas como fuese de su voluntad..."45.

Francisco, sin embargo, no debió acompañar las palabras con los hechos y los regalos tardaron meses en quedar a disposición de su dueña. Esta circunstancia, como veremos, produjo un notable desasosiego y preocupación en Nicolás Juan.

Solventado el tema de la viudedad y a punto ya de concluir el mes de agosto, solicitó Soler el permiso de Nicolás Juan para comunicar "oficialmentc" la noticia a los familiares y evitar con ello que algunos pudieran ofenderse por el retraso:

“...Sienpre que Vmd. jusge ser tiempo de dar quenta á los Parientes se servira avisarme para que nosotros lo agamos aqui sin retarda alguna, para evitar algunas quejas de algunos que sobre este punto se puedan susitar; pues nosotros no sesamos con la mas posible brevedad de hir orrillando cosas para quanto antes llegar al deseado termino de nuestro tratado." 46

Auncue se trasluce en todas sus cartas el deseo de acelerar al máximo los preparativos de la boda, y celebrarla lo antes posible, del tenor de las mismas se infiere que Nicolás Juan no tenía mucha prisa en comunicar la noticia a los parientes. La inexplicable reticencia de su futuro suegro debía tener desconcertado a Francisco Soler, quien no dudó en comentarlo con Jorge Juan: 
"...á tu Hermano Dn. Nicolas tengo escrito disiendole me diga quando quiere que sc de cuenta pues muchos de Ios Parientes estan ya muy quexosos, para enseguida entrar sin retardo á haser la funcion, pues estando ya todo hecho como está no conviene dilatarlo mucho..."47

Cumpliendo diplomáticamente con su labor de intermediario, el marino envió la carta de Francisco a su hermano Nicolás, instando a ambos a llegar a una rápida solución, si bien lo hizo de forma indirecta aprovechando la postdata dirigida a su cuñada María Rita:

"Querida Rita: celebro que no tengas novedad en la salud y tampoco las chicas a quienes me encomiendo de veras. Por el Papel adjunto de Soler veras como dice que él no espera sino la resolución de Nicolas; este dice que la del otro, conque componganse Vms."48

Dado el carácter unilateral del epistolario, integrado casi exclusivamente por las cartas recibidas por Nicolás Juan, las razones que movían a éste a retrasar el comunicado oficial de la boda habrían permanecido ocultas para nosotros si no fuera porque Nicolés conservó un borrador de su contestación:

“...Quedo enterado de la carta de Soler, a q(uie)n. ultimam(en)te, escrivi animandole a q(u)e. comprase los vestidos de la Novia, y se sirviese avisar q(uan)do. todo lo tenga prompto, p(ar)a. dar la cu(en)ta.; y he sabido q(u)e. despues de mi carta ha passado con sus Primas las de Val(enci)a. a Murcia a comprar las ropas, con lo q(u)e. se evidencia incierto lo q(u)e. te supone de tenerlo todo hecho; y mi detencion al no dar parte, hasta que a mi me lo avissase (hablando contigo) no es mas q(u)e. para evitar que se hable, y se pregunte a la muchacha, que regalos ha tenido del Novio, que hasta aora no se ha explicado en cosa alguna, y sea motibo de entibiarla, pues aun el adrezo no le ha visto: y teniendolo todo prompto, y dando cu(en)ta. despues, no se dá liempo $\mathrm{p}(\mathrm{ar})$ a. q(u)e. se hable si ha faltado en algo. Yo creo que esto me lo debiera agradecer Soler, pues es mirarle, como que há de ser hijo.

No obstante si te parece que se dé la cu(en)ta. sin esperar las prevenciones ref(eri)das., que con mucha anticipacion se advirtieron las q(u)e. debía hazer, estoy prompto á exccutarlo con tu aviso,..."49

Aún siendo tan prudente la postura de Nicolás Juan, era imposible dilatar por más tiempo la situación. Cuando Francisco y sus primas llegaron a Orihucla, a su vuelta de la feria de Murcia, se enteraron de que María Rita y sus hijas se encontraban en Orito. Aprovechando la ocasión, se acercaron a este lugar con el fin de que las primas pudieran conocerlas y, de paso, Francisco acordó con su futura suegra los Irámites más adecuados para comunicar la boda:

"...quede convenido con mi Sra. Da. Rita que por el correo de oy diese yo quenta á mis Parientes como lo executo, y que el Lunes salgamos á dar quenta aqui lo que puntualmente assi se hará y que $V$ md. Io practicará el Martes y en el mismo dia escriviráa á sus Parientes, cuyas respuestas aguardaremos para escrivirles yo las grasias, en este particular como en todos los demas espero las instrucsiones y advertencias de Vmd. para acertar en todo." 50 
El 13 de septiembre, Francisco escribió a Nicolás comunicándole que ya había avisado a todos sus parientes, debido a que éstos estaban muy molestos por la tardanza:

"...nos paresio que el retardarlo sería aumentar las quexas, y bien sabe Vmd. que en estos asumtos cada Lugar tiene sus estilos, en los que es presiso conformarse para evitar ruidos y murmurasiones, digolo esto para satisfaser el no cumplir lo que $\mathrm{Vmd}$. me previene de retardar el dar quenta,.." 51

Frente a los hechos consumados, y dado que el novio seguía sin enviar a Rafaela los regalos prometidos, Nicolás optó finalmente por pedírselos, alegando para ello una excusa banal. Aprovechó que su hija debía contestar una carta de su prometido y él mismo, de su puño y letra, redactó el borrador:

“...Ya escriviò a Vm. mi P(adr)e. el motibo de retardar yo esta... y q(uan)do. se determine venir será bien que $\mathrm{Vm}$. trayga la piocha q(ue). me remitio mi tio, y el aderezo, y demas que $V m d$. tenga prompto - pues dessean verlo algunas Paricntas, que sera razon clarlas este gusto..."52

Dicha petición debió ser atendida sin dilaciones pues ya no volvió a mencionarse el asunto en las cartas posteriores. Lamentablemente no se describen en ningún momento las características, aspecto, materiales, etc... de las alhajas regaladas a Rafaela. Cabe pensar por tanto que el aderezo estaría compuesto al menos de pendientes, collar y brazalete o pulsera; mientras que la piocha enviada por Jorge Juan, estaría formada por un pequeño haz de plumas engarzadas en alguna joya, sirviendo normalmente como adorno para la cabeza.

Conocemos, sin embargo, la composición y el valor de algunas otras alhajas que entrarían en posesión de Rafaela a raiz de su boda. Se trata de las joyas propiedad de don Leonardo Soler de Cornellá, padre de Francisco, descritas en el inventario de sus bienes contenido en el convenio, división y partición de la herencia de dicho causante. ${ }^{53}$ Dichas joyas se adjudicaron al primogénito por expresa disposición del difunto ya que éste, en su último codicilo, las incorporó al vínculo establecido sobre parte de sus bienes ${ }^{54}$. De entre los variados objetos de oro, plata y diamantes contenidos en dicho inventario, Rafaela pudo disponer para su adorno personal de un ramo formado por 71 diamantes de diferentes quilates montados en oro y valorado en 134 libras; dos sortijas de oro con 9 diamantes cada una, valoradas conjuntamente en 80 libras; y una cruz y pendientes de oro con 35 diamantes de varios quilates, apreciado todo en 78 libras.

\section{Los vestidos de la novia}

Volviendo a los preparativos nupciales, y siguiendo la cronología impuesta por las cartas, vemos que no fue sino hasta mediados de octubre cuando Francisco pudo realizar el viaje a Valencia que tenía proyectado en un principio para el mes de mayo. Lc acompañaba su hermano Dionisio, a quien familiarmente llama cn las cartas Donís o Dionís. Éste, como ya dijimos anteriormente, era Guardia de Corps 
de la Compañía Italiana de su Majestad con destino en la ciudad de Mérida y, a la sazón, se encontraba disfrutando de un permiso que finalizaba a primeros de diciembre.

El motivo de ir a Valencia era el de comprar allí vestidos y adornos para el hogar, tarea en la que sin duda contaron con la ayuda, asesoramiento y consejo de sus primas, en cuya casa debieron alojarse.

De todos los objetos, ropas y complementos que adquirió Francisco en esta cilldad, conocemos los que seguramente le habían sido encargados por Rafaela o sus padres, debido a que entre las cartas se ha conservado un despacho expedido por el Administrador de Rentas Generales de la Real Hacienda dirigido a la Real Aduana de Valencia. 55

Este documento acreditaba el pago de derechos de determinadas mercancías y autorizaba a Francisco Soler a sacar de la ciudad de Valencia hacia la villa de Elche, en tránsito para entregar a don Nicolás Juan en Alicante, los siguientes artículos:

- un juego de peto, paletina, delantal y lazos de marlí con flores.

- unas guarniciones de blondina y seda para bata.

- una manteleta de encaje negro felpado.

- cuatro pares de medias de seda blancas con cuadrillos bordados.

- ocho pares de guantes de seda blancos y negros.

- 121 varas de tejidos de seda valenciana.

- 3 cajas de lozas compradas a Antonio Areco.

De todos estos artículos hubo de pagar derechos a la Hacienda, excepto de los tejidos, por hallarse éstos exentos.

El martes 18 de octubre, habiendo efectuado todas las gestiones que se le habían encomendado, Francisco escribió a Rafaela desde Valencia comunicándole su propósito de regresar a Elche ese mismo viernes, día 21:

“...el Viernes inmediato sin falta ago quenta de salir para Elche con todos los encargos de aqui (...) procurare luego que llegue a Elche remitirles con la mayor brevedad para que pucda $V$ md. disponer quanto antes gustare los Vestidos que yo por mi parte no me descuidare en reglar lo que resta á disponer en Casa que es muy poco..." 56

El viaje de vuelıa no debió resultarle cómodo ni agradable, debido a las adversas condiciones climatológicas propias del otoño levantino. Las copiosas lluvias que cayeron incesantemente a lo largo del camino entorpecieron la marcha del viajero y determinaron su arribo a Elche con un considerable retraso, puesto que no llegó hasta el día 27. El trayecto de ida y vuelta seguido por Francisco en su viaje a Valencia, debió ser con poca diferencia el mismo que recorrería casi un cuarto de siglo después el viajero inglés Joseph Townsend, ${ }^{57}$ con la única salvedad de que éste salió de Alicante en vez de hacerlo desde Elche. La vía ordinaria más rápida para llegar a Valencia, teniendo en cuenta la pésima situación de las rutas en la época, cra el camino real de Madrid el cual, pasando por Villena y Fuente La Higuera hasta Almansa, se bifurcaba cerca de esta villa hacia San Felipe (Játiva) y Valencia ${ }^{58}$. Alicante y Elche 
distaban de la capital del Turia unas 27 y 25 leguas respectivamente, por lo que viajando a una media de 8 o 9 leguas diarias, que es la distancia cubierta normalmente por Townsend ${ }^{59}$, el viajero inglés empleó tres días del mes de junio en recorrerlas.

Aún suponiendo que Francisco no saliera de Valencia el viernes 21 como decía en su carta, sino el día 22 que es la fecha del despacho expedido por la Real Hacienda, las abundantes lluvias de otoño y el enfangado camino que hubo de recorrer determinaron un retraso de más de dos días sobre lo previsto. Tanto Francisco como su primo Bernardo Juan dieron cuenta de este hecho a Nicolás en sendas cartas fechadas el día 29:

“...Yo llegue de Valencia Jueves por la tarde con muy mal camino, desde Valencia asta aqui no ha cessado de llover discurra Vmd. que tal estaran los caminos..." 60

“...El nobio llego bueno y con todos sus miriñaques haviendole retardado su viaje las muchas lluvias q(ue). assí en Val(enci)a. como en el camino se experimentan..."6l

Una vez en Elche, Francisco envió los tejidos y demás encargos a Alicante con el fin de que se comenzara la confección de los trajes para Rafaela, tarea que debió iniciarse con presteza pues antes de 20 días el trabajo iba muy avanzado:

"...ya me dise Mi Sra. Da. Maria Rafaela que los vestidos se han cortado, y que se va adelantando lo que falta, lo que celebro..."62

También Bernardo Juan, tío de Rafaela, contribuyó con su regalo a aumentar el ajuar de la novia, aliviando en alguna medida los cuantiosos dispendios que la boda debió suponerle a su hermano Nicolás.

Por estas fechas Bernardo debía encontrarse inmerso en los preparativos de su propio enlace. Pese a contar con 47 años de edad y a ser uno de los más acaudalados terratenientes ilicitanos, todavía permanecía soltero. Ignoramos las causas de su prolongado celibato así como las que le indujeron a ponerle fin. Tal vez pesara en su ánimo el deseo de dar un heredero al Señorío de Asprillas, el cual pasó a Bernardo como heredero de los Santacilia. Así, cuatro meses después de la boda de Francisco y María Rafaela, concretamente en abril de 1764 , contrajo matrimonio con Luisá Pascual de Bonanza, de 22 años de edad. Apenas transcurridos tres años, ante la prematura muerte de su esposa, volvería a casar Bernardo, ya cumplidos los 51, con una niña de 15 años, hija de los Condes de Torrellano, llamada María Josefa Vaíllo de Llanos y Pérez de Sarrió ${ }^{63}$. Sin embargo, aunque vivió hasta la avanzada edad de 81 años, no logró descendencia en ninguno de sus matrimonios.

Dotado, pues, de una considerable fortuna y sin los agobios económicos que sin duda debía sufrir su hermano Nicolás para dotar a tan respetable número de hijas, Bernardo determinó regalar a Rafaela un vestido de seda o una bata y comunicó su intención a su cuñada María Rita:

"...tengo animo de regalarle a la Rafaela un vestidillo de seda ya sea $p$ (ar)a. estrado, o $\mathrm{p}(\mathrm{ar}) \mathrm{a}$. Yglesia o una bata, y $\mathrm{p}(\mathrm{ar}) \mathrm{a}$. azertarlo me ha parecido hermanablemente preguntarte $q(u e)$. es lo q(ue). mas convendrá $p(0)$ r. si podemos assi escusar a su Padre de algun gastico; discurro q(ue). no te ofenderas de esta confianza y q(ue). me daras tu aviso..." 64 
No debió ofender demasiado a María Rita semejante libertad, pues antes de cuatro días ya sabía Bernardo el tipo de indumentaria por el que se habían decantado sus parientas:

"Querida Rita: en conformidad de lo q(ue). me insinuas en tu ultima: escrivo p(o)r. el correo de oy a Valencia p(ar)a. q(ue). se tomen la $17 \mathrm{~V}$ (ara)s. de mué negro, cuyo encargo hago a las SS(eñor)as. Marcos q(ue). discurro tendran gusto p(ar)a. eligirle..." $" 65$

Con tan escasos datos no nos es posible determinar la clase de vestido elegido. Si acaso podemos pensar que, necesitándose 17 varas para un sólo vestido, con las 121 varas de tejidos de seda que Francisco compró en Valencia por encargo, pudieron confeccionarse unos 7 vestidos para Rafaela.

Más interesante resulta la alusión que hace Bernardo al estrado. Consistiendo básicamente en un asiento elevado sobre una tarima, se denominaba así por extensión el aposento cuidadosamente amueblado, decorado y alfombrado en cl que las mujeres de determinada condición social veían discurrir la mayor parte de sus vidas entregadas a las actividades consideradas como propias de una dama: costura, pintura, música, y donde recibían a sus amistades. En el siglo XVIII el estrado continuaba vigente y reservado a un mundo mayoritariamente femenino65. Símbolo de la tradicional reclusión en el hogar padecida por la mujer a lo largo de la historia, la progresiva liberalización de costumbres llevaría a admitir en él, excepcionalmente, la presencia de hombres.

La casual referencia que al respecto hace Bernardo Juan nos permite evocar, aunque sea ligeramente, una faceta de la vida cotidiana llevada por las mujeres de las clases sociales más afortunadas. En éste, como en muchos otros aspectos, la nobleza local alicantina se ajusta al patrón establecido.

\section{Capitulaciones matrimoniales y dispensas eclesiásticas}

De una manera lenta pero firme se iban ultimando los preparativos. A finales de octubre Francisco consideraba posible tener todo dipuesto en un plazo máximo de dos semanas. Sin embargo todavía quedaban cuestiones pendientes cuya resolución no podía dilatarse mucho:

“...una de ellas es sobre asumto de cartas matrimoniales, Vmd. de aqui á la vista puede pensar si quiere que se agan antes de la boda ó despues para que me diga aquien devo en todo lanse dar los poderes que son nesesarios..." 67

Era costumbre generalizada, entre familias de distinta localidad, que el novio enviara un apoderado al padre de la novia, con instrucciones detalladas para negociar en su nombre el contenido de las capitulaciones matrimoniales ${ }^{68}$. Lamentablemente no hemos podido hallar la escritura notarial en la que se plasmaría tan importante documento, ni tan siquiera el poder que nos consta otorgó Francisco a tal fin:

“...el poder para cartas esta semana que entra le llevare yo..."69

Sin embargo podemos conocer con exactitud la cuantía de los bienes aportados por Rafacla durante su matrimonio, porque éstos se detallan en el testamento de 
Francisco y en la escritura de inventario, división y partición realizada por sus herederos en 1796. De dichos documentos resulta que constante matrimonio entraron en poder de Francisco un total de 8.886 libras, de las que 4.172 libras constituían la dote, por tratarse de las legítimas paterna y materna de Rafaela, mientras que el resto correspondía a diversas herencias percibidas por ésta y procedentes de distintos familiares 70 .

Otro trámite no menos necesario lo constituía el Breve del obispo de Orihuela, a la sazón don Pedro Albornoz y Tapies, por el que se otorgaba a los contrayentes la dispensa de las tres amonestaciones canónicas impuestas por el Concilio de Trento. Tanto Francisco Soler como Nicolás Juan comunicaron a dicho Vicario la proyectada unión de ambas familias. Dada la categoría de los contrayentes era éste un ineludible deber social para con la jerarquía eclesiástica, acostumbrada a participar en todos los acontecimientos de relevancia.

A su debido tiempo recibió Nicolás la efusiva enhorabuena del Obispo junto con la seguridad de que dispensaría a los contrayentes de todo aquello que estuviera en su mano $^{71}$. Idéntica comunicación recibió Francisco:

"... de su lima. tuve respuesta muy atenta disiendo nos dispensara todo lo que sea dable, con que estamos bien."72

Obtenido el Breve del Obispo, Francisco se lo envió a Rafaela por medio de un criado de confianza. Días después, no habiendo recibido noticias de Nicolás relativas a la recepción de dicho documento y visiblemente inquieto ante el posible extravío del mismo, informó de ello a su futuro suegro:

“...escriví a mi Sra. Da. Maria Rafaela incluyendole dentro de la Carta el breve para nuestro desposorio, y aunque confio en que no se haya perdido un papel tan nolable como este, porque el moso es de confianza y sabia lo que llevava, con todo me tiene con cuidado no haverme trahido el respuesta del recibo (...) por lo que he de dever a Vmd. se sirva desirme si este papel llegó, o, no en la carta que imbie con el dicho Moso para poderme sosegar en el cuidado en que estoi." 73

Aunque no conocemos la contestación de Nicolás, sabemos que el Breve llegó a su destino sin mayores problemas; prueba de ello es que en la inscripción del matrimonio llevada a cabo en los Libros parroquiales de la Iglesia de San Nicolás de Alicante, se recoge su otorgamiento ${ }^{74}$.

\section{La boda}

Por increible que parezca, nueve días antes de la celebración del enlace todavía no estaba fijada la fecha del mismo. Finalizado el mes de noviembre sin haber conseguido ultimar todos los preparativos y reincorporado Dionisio, suponemos, a su destino en Mérida, los esfuerzos de Francisco se dirigieron a lograr que la boda se celebrara antes de Navidad. La razón de su empeño había de buscarse ahora en el hecho de que, deseando que fuera su hermano Leonardo quien oficiara la ceremonia, éste debía reintegrarse sin falta, pasadas esas fechas, a sus obligaciones al frente de la parroquia de Almoradí. 
Por otro lado existía un motivo de satisfacción dado que, finalmente, se confirmaba la asistencia de Jorge Juan. Sobre este punto cabe señalar que, apenas dos meses antes, Francisco lamentaba la imposibilidad de que el marino estuviera presente en acontecimiento tan señalado:

"...bien sabe Dios el gusto que yo tuviera de que tu estuvieses aqui, y que nos asisticras en la funcion pero ya veo no puede ser pasiensia y esperaremos tener el gusto de verte quando te desocupes de la tareas que deseo no te quebranten la salud..."75

El lógico deseo de reposo y descanso para buscar cierto alivio a las muchas dolencias que, desde hacía años, padecía el científico determinó el cambio de planes, y Jorge Juan emprendió viaje desde Madrid hacia Alicante el día 25 de novicmbrc ${ }^{76}$, llegando a esta ciudad antes del 9 de diciembre, como pone de manifiesto Francisco:

"...celebrando el gusto del arribo de Jorge, tan aliviado como me disen que viene grasias a Dios de sus quebrantos." 77

Sin embargo, la fecha de la boda seguía sin fijarse y aunque la paciencia y tolerancia de Francisco, de su tío don Pedro y demás hermanos eran muy grandes, no debían ser infinitas. No en vano había expuesto insistentemente a Rafaela y al hermano de ésta, Frasquito, los enormes perjuicios que le estaba suponiendo el retraso.

Intentando conjugar del mejor modo posible todos los factores en juego, Francisco comprendía que celebrar la boda antes del día 15 era muy precipitado, por la necesidad que tenía Jorge Juan de reponerse del agotador viaje, mientras que a su hermano Leonardo le era imprescindible que se efectuara antes de Navidad; por ello exhortó a Nicolás a disponerlo todo para que antes del día 19 se hubiera celebrado la ceremonia:

"...hallandose mi hermano Leonardo con la presision de marchar a otro dia de Navidad a su Curato (...) tendria yo el sentimiento de que este Hermano no me asistiesc, por lo que suplico a Vmd. cncarecidamente (...) se digne disponer las cosas de forma que dicho dia dies y nueve llegue aqui esta Señora, pues de lo contrario aseguro á Vmd. causará en mi tio, y en todos los de esta de Vmd. un sumo disgusto..."78

El 10 de diciembre, Francisco escribió la última carta que de él se conserva en el legajo. En ella comunicaba a Nicolás que, reunido con Bernardo:

"...hemos resuelto sea la funcion el Domingo 18 de los corrientes, pues $\mathrm{cl}$ ser los dias que se les subsiguen al Jueves, y Lunes ayuno de precepto les hase algo incomodos, por lo que nos ha paresido el Domingo mejor dia, que aunque es dia de precepto el tencr Oratorio en casa Vmd. facilita el embaraso que pudiera haver de la Misa; por este motivo y porque los cosineros no esten aqui tantos dias detenidos no imbiare la galera asta el miercoles, que hira sin falta para que en los dias Jucves, Viernes, y Sabado prevengan los trabajos, y el Sabado bolvera á hir para traer Cofres, y demas que Vmd. mande." 79

Esta vez Nicolás Juan no tuvo nada que objetar. Solucionados todos los problemas, y dejando atrás largos meses de preparativos, Francisco Soler y Rafaela Juan contrajeron matrimonio en la Colegial de San Nicolás de Alicante, en presencia del Dr. D. Leonardo Soler, cura de la parroquia de Almoradí. Fueron dispensados de las tres amonestaciones canónicas por Despacho del Obispo, dado en Orihuela el 28 de 
noviembre de 1763; y actuaron como testigos don Jorge Juan, caballero del Hábito de San Juan de Malta y Jefe de Escuadra de la Real Armada, don Bernardo Juan, don Pedro Soler y otros 80 .

\section{LA PROYECCIÓN SOCIAL DEL ENLACE}

Como ya dijimos anteriormente, entre las cartas conservadas se encuentra un pequeño borrador escrito por Nicolás Juan, en el que detalla el nombre de los familiares y amigos a los que debía comunicar la boda de Rafaela ${ }^{81}$. Entre ellos aparecen muchos nobles titulados como los condes de Torrellano, Carlet, Organya y la condesa de Berbedel; los marqueses de Arneba, Albaida, Ayerbe, Cañízar, Lazán y Villalón; el barón de Escrich y la baronesa de Sangarren.

Dado que tanto Francisco como Nicolás retrasaron hasta mediados de septiembre de 1763 el anuncio "oficial" del enlace, las felicitaciones y enhorabuenas se recibieron entre el 20 de septiembre y el 11 de octubre de ese año. Varias de las cartas procedían de Zaragoza, ciudad natal de María Rita Ximénez de Urrea y en la que vivían sus parientes.

En todas sin excepción se vertían muy favorables comentarios sobre el proyectado casamiento, elogiando tanto los méritos y circunstancias de nobleza del novio como las singulares prendas de la novia.

Resulta curioso que algunas cartas aludan al próximo matrimonio de Rafaela como si de un buen empleo se tratase:

"...no me toca sino el celebrar y darme mil enhorabuenas de la colocacion de la parienta con el Sor. Dn. Francisco Soler tan destinguido en su Nobleza..."82

“...y que tu y el P(arien)te. Sr. Dn. Nicolas tengais la satisfacion, y consuelo de ver a buestras amables Hixas e Hixo, tanbien colocadas como se merezen..."83

"...recivo la tuya con mucho gusto (...) por la buena noticia, que me das de la proxima colocacion de tu Hija que celebro mucho..." 84

Por el contenido de las cartas se infiere que la comunicación del enlace fue doble en muchos casos, pues mientras Nicolás se hizo cargo de escribir la noticia a los parientes y amigos, María Rita hizo lo propio con las esposas de éstos:

“... de mi S(eñor)a. Da. Rita (...) la q(u)e. ha escrito a mi muger, y no tenia Vs. q(u)e. haverse cansado en escrivirme separadamente pues entre Nosotros era ocioso cumplimiento..."85

Así pues, las contestaciones también se duplicaron existiendo una gran dilerencia entre el contenido de las dirigidas a Nicolás y aquellas cuya destinataria era María Rita. Los corresponsales masculinos, mucho más concisos y protocolarios, se limitaron a formular los mejores deseos hacia el futuro de la pareja, con la única excepción de un amigo de Cartagena, el cual también incluyó noticias referentes a la Marina: 
“...En este Correo a avido Cartas de las Alusemas en las que disen se mantenian todos buenos, y que saldrian de alli p(ar)a. continuar su comision luego; por lo que me persuado no tarden en bolber a esta el armamento al que se le a agregado el Sptentrion que el otro dia partio para yncorporarse con ellos." 86

Muy distintas son las cartas de las mujeres, con un tono más elevado de familiaridad y cariño en el trato. A través de ellas es posible conocer pequeños detalles de la vida diaria tales como enfermedades, nacimientos, ascensos, etc...:

"...y no te escrive la enorabuena porque esta todavia algo delicada de cl Mal parto que tubo dias pasados de dos Messes y siete dias..."87

"...ofresco a tus pies el asenso de mi chico que le an dado bandera en su misma compañia y marcha luego a Barcelona..." 88

“...por que se te as de alegrar por si acaso no bes la gazeta te digo an echo Alferez de guardias ami sobrino Perico Urries." 89

Gran parte de las cartas están escritas por distinta mano de la que las firma. Algunas incluso repiten el mismo texto prácticamente, como si en primer lugar fueran escritas al dictado por un secretario o servidor y, posteriormente, el firmante quisiera demostrar un aprecio o consideración especial hacia el destinatario añadiendo algunas frases más familiares. Precisamente a ello se refiere una de las primas de María Rita, utilizando un estilo y grado de confianza ciertamente extraordinarios:

"...sienpre que me as escrito te erespondido y con la diferencia de ser sienpre de mi mano y ati nunca te faltan escusas para azerlo de la ajena pero yo no me formalizo ni me pico de cstas cosas (...) sino que tu eres una quejona biziosa y que te tengo mal acostumbrada con mis bicios..."90

No faltan, en fïn, las referencias a fiestas y diversiones, acompañadas de irónicos comentarios acerca del nuevo estado que pronto tomaría Rafacla. Estos comentarios estaban realizados precisamente por su propia hermana María Francisca, Ia joven marquesa de Arneva:

“...A Rafacla qe. tenga pasiencia y qe. empiese a llebar la cruz del Matrim(oni)o. (...) Aqui hay este Domingo que viene comedia, representada por unos farcantes mui buenos, vengan Vm. y se dibertiran, pues pueda ser ayga Baquitas, y Hay mui buenos fuegos." 91

Las palabras de María Francisca denotan resignación y un ligero desencanto. Seguramente no le faltaban motivos ya que, a sus 20 años y casada desde los 14 años con un noble viudo que le doblaba la edad, había sufrido la pérdida de un hijo y continuaba sin sucesión. Así lo manifiesta una parienta de María Rita en su carta:

"...dala a la Novia mil parabienes (...) y a m(ari)a. fr(ancis)ca. y su marido que celebraremos esten con s(alu)d. y que d(io)s. les de sucesion ya que se les llevo el Niño..."92

Queda en la sombra, sin embargo, un aspecto fundamental dentro del estudio acometido. El epistolario conservado nada o casi nada puede mostrarnos acerca de las relaciones personales entre los novios. Apenas dos cartas de Francisco Soler tic- 
nen a Rafaela como destinataria, y ello porque previamente había solicitado el permiso de Nicolás Juan para podérselas enviar:

"...con motivo de cumplir sin retarda este encargo escrivo yo a mi Sra. Da. Rafaela dos Letras. Suplico a Vmd. disimule este atrevimiento, y me permita tener respuesta de esta Señora si se dignase honrarme con sus Letras, que para mi seran de sumo apresio y estimasion." 93

Lógicamente la correspondencia recibida por Rafaela pasaba ineludiblemente por las manos de su padre. Ello no obstante, el tono empleado por Francisco Soler reúne a la vez una exquisita cortesía con expresiones que denotan un alto grado de cariño y deseo de ver y hablar a su novia:

"...ya en el Orito la signifique quanto deseava ver letra de $V m$ m. con este motivo ratifico a los pies de Vmd. mi voluntad, mi afecto, y todo mi corason que la estima y ama y amara perpetuamente..."94

"...ya la escrivire yo a Vmd. para tomar sus ordenes, y tanbien el permiso de poder pasar a verla aunque no sea mas de una noche, pues ya se hara Vmd. cargo quanto lo deseo, y quan escasamente he podido lograr este bien en un año..."95.

Por el contrario, la única carta que figura en el legajo dirigida por Rafaela a su prometido es un borrador escrito de puño y letra de su padre. Ignoramos si las secas y formularias frases de cortesía sugeridas por su progenitor se verían posteriormente adornadas y suavizadas por mano y voluntad de la interesada:

"Muy Sr. mio: Recibi con grande agrado la carta de Vm. estimando las exp(resione)s. que le meresco a las que corresponde mi cincera gratitud como es debido..."

Resulta inútil por ello intentar extraer alguna conclusión acerca del ánimo o inclinación sentidos por la joven hacia quien había de ser su esposo. Es lamentable que la falta de correspondencia cruzada $y$, por ende, la inexistencia o desaparición, si es que la hubo, de una relación epistolar más fluida y constante entre los novios no nos haya permitido profundizar en aspectos más íntimos e interesantes del tema abordado.

El presente trabajo representa un ejemplo, pormenorizado en este caso, de la complejidad que podía entrañar la celebración de un enlace entre miembros de la pequeña nobleza urbana. El acuerdo para llevarlo a cabo, la preparación del evento en exceso dilatada en el tiempo-, los regalos, la preocupación por los detalles más nimios, los invitados, etc... son los ingredientes esenciales que forman parte e intervienen en un concreto acontecimiento. En el presente caso la minuciosa documentación manejada nos ha permitido alcanzar un detalle poco habitual. 


\section{APÉNDICE DOCUMENTAL}

Francisco Soler de Cornellá a Nicolás Juan, Elche 16 de abril de 1763:

"Muy Señor mio, y mi dueño: por mis hermanos tengo el gusto de saber dela felis salud de Vm. y de Mi Sra. Da. Rita y de mi Sra. Da. Rafaela y demas Señoras acuyos pies me ofresco con el mas imutable afecto, logrando ygual benelicio con mi tio y hermanos que hasen a Vm. y Señoras las devidas expresiones.

Haviendose orillado todas las dependiencias de casa entre los hermanos con la mayor armonia, y quedado arreglada la division y particion de todos los bienes con reciproca satisfacsion de los hermanos y mia, y con estabilidad firme para que en lo sucsesivo no pueda haver la menor alterasion, inmediatamente procuré arreglar todas las Diligencias judiciales presisas para la Consecusion de la convenida viudedad ì favor de Mi Sra. Da. Rafaela, las que en efecto en este dia tengo remitidas al Agente para su presentasion en el Consejo, y escrito a Jorge para que estando a la vista al tiempo de la terminasion procure sea esta con las mayores ventajas; lo que participo a $\mathrm{Vm}$. para que enterado del estado de este particular, vea los pasos que le paresiere adelantar en nuestro asumto, pues yo con los deseos de sin demora alguna orillar lo que esta à mi cargo, siempre que Vm. y essas Señoras me lo permitan delibero por todo este mes pasar à Valencia a tomar Vestidos, y adornos de cassa, sobre cuyo particular si Vm. ò essas Señoras tuviesen algo que mandarme estimare me lo prevengan, y reiterando mi rendido y obligado afecto para q(uan)to. Vm. mandara y sirviendose ponerme a los pies de essas Señoras quedo con los deseos de que se mantengan con la mas feliz salud, y que Dios g(uar)de. à Vm. m(ucho)s. a(ño)s. Elche y Abril 16 de 1763.

BLM de Vm. Su Af(ec)to. oblig(a)do. ser(vido)r. y Amigo

Fran(cis)co. Soler de Cornellá.

Sor. Dn. Nicolas Juan".

Francisco Soler de Cornellá a Nicolás Juan, Elche 21 de mayo de 1763:

"Muy Sor. mio y mi Dueño: celebrare que Vmd. disfrute la mas feliz salud en conpañia de mi Sra. Da. Rafaela y demas Señoras á cuyos pies me ofresco con todos los de esta de Vmd., quienes deseamos tenga Vmd. el dia de Santa Rita muy feliz y alborosado, cuya expresion suplico a Vmd. pase de mi parte y de la de mi tio y 
Hermanos á mi Sra. Da. Rita a quien la deseamos la mayor satisfacsion por muchos dias de este.

de Madrid tuve el Correo pasado carta del agente en que me dise se estava ya viendo en el Consejo en la Junta de Viudades el expediente de la pretension nuestra, y que confiava se despacharia quanto antes; y por sí acaso se nesesita inbiar algun otro papel ó preparar alguna otra diligencia en este expediente por aqui no me atrevo a ausentarme de esta, asta que tengamos fuera la Viudedad;

Y no ocurriendo otro particular y reiterando mi invariable afecto á los pies de mi Sra. Da. Rita y de mi Sra. Da. Rafaela quedo esperando ocasiones en que enplearme en el servicio de Vmd. al que quedo rog(an)do. á Dios le g(uar)de. m(ucho)s. a(ño)s. que deseo Elche y Mayo 21 de 1763.

B.L.M. de Vmd. su af(ec)to. ap(asiona)do. y oblig(ado). ser(vid)or. y Amigo Fran(cis)co. Soler de Cornellá

Sor. Dn. Nicolas Juan".

Francisco Soler de Cornellá a Nicolás Juan, Elche 11 de junio de 1763:

"Muy Señor mio y mi Dueño: celebrare que Vmd se mantenga con la mas cabal salud y que en este beneficio le acompañen Mi Sra. Da. Rita, Mi Sra. Da. Rafaela y demas Señoras a cuyos pies me ofresco con toda voluntad como mi tio y Hermanos, quienes nos mantenemos sin novedad para quanto Vmds. quisieren mandarnos. Jorge me inbio estos dias el adereso de mi Sra. Da. Rafaela, con una piocha muy linda conque el de su parte regala á esta Señora, a quien dira Vmd puede disponer de estas Alajas como fuese de su voluntad, las que por el buen gusto de su director confio seran del suyo, en lo que afianzare yo mi satisfacsion.

del Agente tuve estos dias pasados carta disiendome que de un dia para otro està para salir el decreto de Viudedad, de cuya resulta imediatamente dare aviso á Vmd., teniendome inpasiente esta demora aunque bien considero que en el Consejo no se negosia con la ligeresa que por aqui.

y no ocurriendo otro particular reitero á Vmd. mi indeleble voluntad suplicandole se sirva pasar mis respetos con particulares expresiones á los pies de Mi Sra. Da. Rita, y Mi Sra. Da. Rafaela, interin quedo rog(an)do. á Dios g(uar)de. á Vmd. m(ucho)s. an(o)s. elche y Junio 11 de 1763.

B.L.M. de Vind. su af(ec)to. s(e)g(u)ro. servidor y Amigo.

Fran(cis)co. Soler de Cornellá

Sor. Dn. Nicolas Juan". 
Francisco Soler de Cornellá a Nicolás Juan, Elche 6 de agosto de 1763:

"Muy Sor. mio y mi Dueño: celebrare que Vmd. disfrute la mas feliz salud, y que en este beneficio le acompañen Mi Sra. Da. Rita, Mi Sra. Da. Rafaela y demas Señoras á cuyos pies me ofresco con mi tio y Hermanos quienes nos mantenemos sin novedad para servir á Vmd.

participo á Vmd. como en este Correo me ha remitido el Agente de Madrid la cedula real para la viudedad de mi Sra. Da. Rafaela, dandome el Rey facultad para que sobre los bienes de mis vinculos pueda señalar á esta Señora la cantidad de ciento y ochenta y nueve libras, sin enbargo de que lo que se pidio fueron doscientas libras como quedamos acordados. yo huviera querido que huvieran sido mucho mas, y para ello hise quanto puede poniendo este negocio en manos y direcsion de Jorge, que es el que lo ha dirijido, quien no dudo havra hecho su dever; con todo no ha salido csta viudedad tan regulada como la de Mi Sra. Da. Manuela su hija de Vmd. que al mismo tiempo se ha pedido, y siendo assi que las rentas de los vinculos de Juan Roca son mas que duplicadas de las mias solo se le han consedido doscientas libras, que son onze pesos menos la mia; con todo ofresca $V m d$. en mi nombre este pequeño obscquio á Mi Sra. Da. Rafaela con todo mi indeleble afecto.

en este estado Vmd. me dira los pasos que en este asumto se huviesen de adelantar, segun Vmd. y Mi Sra. Da. Rita lo discurrieren regular; que aqui quedamos con el cuidado de arreglar tan pronto como se pasen estas fiestas los vestidos y adornos que faltan, lo que no esta ya hecho por esperar saliese la viudedad por si era menester alguno otra diligencia que haser, pero tan promto como se vayan mis Parientas las de Valencia que las espero para estas fiestas, procuraremos arreglarlo todo con la brevedad posible; es quanto ocurre molestar á Vmd., a cuya obediencia quedo con el mayor afecto rog(an)do. á Dios le g(uar)de. m(ucho)s. an(o)s. elche y Agosto 6 de 1763.

B.L.M. de Vmd. su Afecto y Seg(u)ro. S(ervid)or. y Amigo.

Fran(cis)co. Soler de Cornellá

Sor. Dn. Nicolas Juan".

Francisco Soler de Corncllá a Nicolás Juan, Elche 20 de agosto de 1763:

"Muy Sor. mio y mi Dueño: deseo que Vmd. logre la mas cabal salud en compañia de Mi Sra. Da. Rita Mi Sra. Da. Rafaela y demas Señoras á cuyos pies me 
ofresco como mi tio Dn. Pedro y Hermanos, quienes apresian las afectuosas expresiones de Vmd. y las debuelven, quedando sin novedad todos para servir á Vmds.

tuvimos el gusto estas fiestas de ver á mi Sra. Da. Maria Fran(cis)ca. y Sannasar, a quienes en conformidad de lo que Vmd. me previene en su antesedente di quenta de nuestra tratada boda con las expresiones correspondientes á la condesendensia de cosas tan propias como estos Señores en que me han favoresido; vio esta Señora el adereso de Mi Sra. Da. Rafaela que le paresio muy bien.

Sienpre que Vmd. jusge ser tiempo de dar quenta á los Parientes se servirá avisarme para que nosotros lo agamos aqui sin retarda alguna, para evitar algunas quejas de algunos que sobre este punto se puedan susitar; pues nosotros no sesamos con la mas posible brevedad de hir orrillando cosas para quanto antes llegar al deseado termino de nuestro tratado. Sirvase Vmd. de haser una muy particular expresion de mi indeleble afecto á mi Sra. Da. Rafaela á cuyos pies me sacrifico con toda mi voluntad deseando sus preceptos.

Bernardo retorna las memorias á Vmd. que de su parte le di, y yo repitiendome á los pies de mi Sra. Da. Rita y demas Señoras, y á la obediencia de Vmd. quedo esperando sus Ordenes para obedeserlas con toda puntualidad y en el interin ruego á Dios le g(uar)de. m(ucho)s. an(o)s. elche y Agosto 20 de 1763.

mis Primas aun se mantendran aqui por todo este mes no obstante Vmd. delibere lo que Vmd. jusgare mas del casso.

B.L.M. de Vmd. su mas af(ec)to. y oblig(a)do. serv(id)or. y Am(i)go.

Fran(cis)co Soler de Cornellá

Sor. Dn. Nicolas Juan".

Francisco Soler de Cornellá a Nicolás Juan, Elche 27 de agosto de 1763:

"Muy Señor mio y mi dueño: celebrare que Vmd se mantenga con la más leeliz salud, y que en este beneficio le acompañen mi Sra. Doña Rita Mi Sra. Doña Rafaela y demas Señoras á cuyos pies me ofresco con todo respeto con mis hermanos y tio Dn. Pedro que hasen á Vmd. y Señoras las devidas expresiones.

oy hase ocho dias escrivi á Vmd. otra y en ella le manifestava como al paso de mi Sra. Doña Maria Fran(cis)ca. y Sannasar por esta (que tuvimos el gusto de disfrutar su compañia en la fiesta) les di la correspondiente quenta de mi boda como Vmd. me lo prevenia, de cuya carta no he tenido respuesta lo que me tiene en cuidado por si alguno de essa mi estimada cassa se halla indispuesto lo que sentiria mucho Dios quiera no sea assi y que todos se mantengan con robusta salud, por lo que he de 
dever á Vmd. se sirva tomar el trabajo de escrivirme para salir de cuidado, pues en estos dias pasados me dijeron se hallava Mi Sra. Da. Rafaela algo resfriada. en los demas particulares de mi antesedente tanbien espero rason de Vmd. á quien suplico se sirva pasar a Mi Sra. Da. Rafaela una muy particular expresion de mi afecto á cuyos pies me ofresco con todo corazon para quanto esta Señora gustasse mandarme.

Mi Hermano Dionisio con los deseos de ver á Vmds. y tener el gusto de conoser á Mi Sra. Da. Rafaela pasará un dia de estos á essa Ciudad, imediatamente procurara hir á casa de Vmd. para que Vmds. le reconoscan por su seguro afecto servidor; y no ocurriendo otro particular repitiendome á los pies de mi Sra. Da. Rita quedo á las Ordenes de Vmd. rog(an)do. á Dios le g(uar)de. m(ucho)s. a(ño)s. Elche y Agosto 27 de 1763.

B.L.M. de Vmd. su seg(ur)o. Afecto ser(vid)or. y Amigo

Fran(cis)co. Soler de Cornellá

Sor. Dn. Nicolas Juan".

Francisco Soler de Cornellá a Jorge Juan Santacilia, sin fecha pero anterior al 3 de septiembre de 1763, según se infiere de la carta siguiente:

"Para mi Primo Dn. Jorge Juan.

Q(ueri)do. Jorge me halegrare te halles bueno, cuyo beneficio disfrutamos en casa todos para servirte, quienes te saludan.

ya sabes que en el papel de mis encargos te puse compraras un tocador de Charol conpuesto de espejo dos Cofresitos cajas y otros Miriñaques presisos de damas, quando vino el adereso, á ti se olvido conprarle y á mi haserte memoria, y haviendolo buscado por aquí no se encuentra, por lo que estimare agas que se conpre, y me avises de su importe para remitirtelo, pues ya sabes que es alaja presisa.

á tu Hermano Dn. Nicolas tengo escrito disiendole me diga quando quiere que se de cuenta pues muchos de los Parientes estan ya muy quexosos, para enseguida entrar sin retardo á haser la funcion, pues estando ya todo hecho como está no conviene dilatarlo mucho. bien sabe Dios el gusto que yo tuviera de que tu estuvieses aqui y que nos asistieras en la funcion pero ya veo no puede ser pasiensia y esperaremos tener el gusto de verte quando te desocupes de las tareas que deseo no te quebranten la salud.

no ocurre otra cosa pasalo bien y manda á tu Primo de corazon.

Fran(cis)co. Soler

Q(ueri)do. P(ri)mo. Jorge". 
Jorge Juan a Nicolás Juan, Madrid 3 de septiembre de 1763. Está escrita casi en su totalidad de puño y letra de Miguel Sanz, secretario de Jorge Juan, aunque firmada por éste:

"Quer(id)o. Nicolás: Mucho me alegro que en la Fontcalent desfrutes tu tan cumplida salúd como me aseguras en tu ultima, como que en Alicante logren tambien igual veneficio, que, à Dios gracias, consigo yo del mismo modo para servirte, deseando que esta dicha continue à todos, y que si en algo te puedo servir me mandes con las veras que pido à Dios te gu(ard)e. m(ucho)s. a(ño)s. Madrid y Sept(iembr)e. 3 de 1763 -

(Con letra de Jorge Juan) tuyo de Corazon Jorge.

(Escrito de puño y letra de Jorge Juan):

Querida Rita: celebro que no tengas novedad en la salud y tampoco las chicas a quienes me encomiendo de veras. Por el Papel adjunto de Soler veras como dice que èl no espera sino la resolucion de Nicolas; este dice que la del otro, conque componganse Vms.

De Frasquito no puedo decirte sino que se halla embarcado: pedir que se desembarque para la licencia no me parece regular. Si para el lance preciso se hallase en Cartagena bien podrà ir pues por 15020 dias el Comandante se los podrà conceder. Lo de Batallones es una pamplina.

Deseo à Vms. mucha salud y que manden asu afectissimo (Ilegible) Jorge".

Nicolás Juan a Jorge Juan, Alicante 7 de septiembre de 1763. Borrador:

\section{"Copia}

Quedo enterado de la carta de Soler, a q(uie)n. ultimam(en)te., escrivi animandole a q(u)e. comprase los vestidos de la Novia, y se sirviese avisar q(uan)do. todo lo tenga prompto, $\mathrm{p}($ ar)a. dar la cu(en)ta.; $y$ he sabido, $\mathrm{q}(\mathrm{u}) \mathrm{e}$. despues de mi carta ha passado con sus Primas las de Val(enci)a. a Murcia a comprar las ropas, con lo q(u)e. se evidencia incierto lo q(u)e. te supone de tenerlo todo hecho; y mi detencion al no dar parte, hasta que a mi me lo avissase (hablando contigo) no es mas q(u)e. para evi- 
tar que se hable, y se pregunte a la muchacha, que regalos ha tenido del Novio, que hasta aora no se ha explicado en cosa alguna, y sea motibo de entibiarla, pues aun el adrezo no le ha visto: $Y$ teniendolo todo prompto, y dando cu(en)ta. despues, no se dà tiempo $\mathrm{p}($ ar)a. $\mathrm{q}(\mathrm{u}) \mathrm{e}$. se hable si ha faltado en algo. Yo creo que esto me lo debiera agradecer Soler, pues es mirarle, como que hà de ser hijo.

No obstante si te parece que se dè la cu(en)ta. sin esperar las prevenciones ref(eri)das., que con mucha anticipacion se advirtieron las q(u)e. debia hazer, estoy prompto à executarlo con tu aviso, como q(uan)to. sea de tu agrado, y q(ue)do. $\mathrm{p}(\mathrm{ar}) \mathrm{a}$. servirte rog(an)do. a $\mathrm{D}(\mathrm{io}) \mathrm{s}$. te gu(ard)e. $\mathrm{m}($ ucho)s. y felizes a(ño)s. Alic(an)te. 7 de 7 bre. de 63.

(ilegible) Nicolás

Q(uerid)o. H(erman)o. Jorge".

Jorge Juan a Nicolás Juan, Madrid 10 de septiembre (de 1763). Escrita por Miguel Sanz, va firmada por Jorge Juan:

"Quer(id)o. Nicolás: Por tu carta quedo enterado del motivo de tu detenc(io)n., q(u)e. me ha parecido muy prudente. Solér me escribe ahora contestando lo proprio; pero asegurando esta quasi pronto: à mì me tiene encargado un tocador, $q(\mathrm{u}) \mathrm{e}$. breve harè la diligencia.

Me alegrarè que vaya muy bien en Orito à Maria Rita y las Chicas, igualm(en)te. que en el Hondón.

De Frasq(ui)to. tamb(ie)n. he tenido carta, en q(u)e. me dice buelve à salìr en su Jabeque, por hallarse fuera los Navios y Frag(a)ta. en q(u)e. se le podria dàr otro destino.

Ante-noche sucediò la desgracia de un incendio en esta Yglesia Parrochial de S(an)ta. Cruz, despues de una gran funcion q(u)e. se celebrò el mismo dia, cuyos adornos de Plata labrada y joyas, uno y otro en bastante cantidàd no se sabe la suerte que han tenido, por que à mas de haber sido general el fuego en todos los Altares y demàs obras de Maderas; $p$ (ar)a. ahogarlo derribaron techos y Bovedas, cuyas ruinas cubren todo, y aùn subsiste algun fuego debaxo de ellas.

Deseo q(u)e. lo passes bien; yo, à Dios grac(ia)s., no tengo novedad, y deseo que mandes, con las veras que puedes à tu m(a)s. af(ect)o. (Con letra de Jorge Juan) Herm(an)o.

Jorge

Madrid 10 de Sept(iembr)e". 
Francisco Soler de Cornellá a Nicolás Juan, Elche 10 de septiembre de 1763:

"Muy Señor mio y Amigo: celebrare que Vmd. se mantenga bueno, cuyo beneficio disfruto para servirle, con mi tio Dn. Pedro y Hermanos quienes saludan á Vmd. con todo afecto.

Haviendo sabido al paso por Orihuela, que mi Sra. Da. Rita y demas Señoras estarian los dias de la fiesta en el Orito dispuse pasar alli con mis Primas, quienes celebraron mucho el conoser a las Señoras y espesialmente á Mi Sra. Da. Rafaela; quede convenido con mi Sra. Da. Rita que por el correo de oy diese yo quenta á mis Parientes como lo executo, y que el Lunes salgamos á dar quenta aqui lo que puntualmente assi se hará y que Vmd. lo practicará el Martes y en el mismo dia escrivirá á sus Parientes, cuyas respuestas aguardaremos para escrivirles yo las grasias, en este particular como en todos los demas espero las instrucsiones y advertencias de Vmd. para acertar en todo.

Ya dije á las Señoras todo lo que he traido de la feria, lo qual vieron en Orihuela Mi Sra. Da. Franca. y mi Sra. Da. Manuela y les gustó mucho, y en lo demas que falta no ceso de hirlo arreglando, pues una ves que todo está hecho y se concluya lo demas estimare no me retarde Vmd. el feliz dia de mi fortuna.

Celebrare que las Señoras lleguen buenas esta noche del Ondon y que se ayan divertido pongame Vmd. asus pies con particulares expresiones á Mi Sra. Da. Rafaela, y reciba Vmd. y Señoras memorias de Bernardo que me lo encarga; y no ocurriendo otro quedo de Vmd. con indeleble voluntad rog(an)do. á Dios Le g(uar)de. m(ucho)s. an(o)s. Elche y 7 bre 10 de 1763

B.L.M. de Vmd. su s(e)g(u)ro oblig(a)do. y afec(tuo)so. serv(id)or.

Sor. Dn. Nicolas Juan".

Francisco Soler de Cornellá a Nicolás Juan, Elche 13 de sepliembre de 1763:

"Muy Señor mio y mi Dueño, celebro que las Señoras se hayan restituido del Ondon con felisidad, y que con Vmd. se mantengan buenas, cuyo beneficio disfruto con el tio Dn. Pedro y los hermanos que apresian y debuelven á Vmd. y á las Señoras sus memorias, a cuyos pies nos of resemos con imutable cariño.

en este Correo escrivo á las Primas Da. Margarita y Da. Maria Antonia, y a! 
amigo Dn. Cipriano y por el correo de Cartagena no le he escrito al Amigo Dn. Franco. su hijo de Vmd. porque me han dicho salieron los Javeques pero le encargo á Postigo me avise tanpromto como llegue para no faltar á esta presisa y devida obligasion.

aqui no hemos podido retardar el dar quenta ayer porque como el Domingo por la tarde quedó todo arreglado con mis tios, y los mas de los Parientes me estavan hasiendo ya muy de los serio y teniamos escrito á los de Orihuela y de otras partes nos paresio que el retardarlo seria aumentar las quexas, y bien sabe Vmd. que en estos asumtos cada Lugar tiene sus estilos, en los que es presiso conformarse para evitar ruidos y murmurasiones, digolo esto para satisfaser el no cumplir lo que Vmd. me previene de retardar el dar quenta, á Bernardo le he enterado de todo de parte de Vmd., pues de la mia á todo está presente, reciba Vmd. memorias de su parte, y de la mia paselas á Mi Sra. Da. Rita y demas Señoras, hasiendo una expresion muy particular á mi Sra. Da. Rafaela de todo mi Corazon, y no ocurriendo otro particular quedo muy de Vmd. rog(an)do. á Dios le g(uar)de. m(ucho)s. a(ño)s. Elche y 7 bre 13 de 1763.

B.L.M. de Vmd. su seg(ur)o. afe(ctuo)so. Amigo y ser(vid)or.

Franco. Soler de Cornellá

Mis Primas marcharon ayer mañana y me encargaron mil expresiones para las Señoras y Vmd.

Sor. Dn. Nicolas Juan".

Jorge Juan a Nicolás Juan, Madrid 17 de septiembre (de 1763). Escrita por Miguel Sanz excepto la firma y postdatas:

"Qucr(id)o. Nicolàs: rec(ib)o. tu carta de 14 del corr(ien)te., y celebro infinito $\mathrm{q}(\mathrm{u})$ e. assi tu, como M(ari)a. Rita y las Chicas logreis cumplida salúd, y que unos y otros hos hayais dibertido mucho en la Feria del Orito. Yo, à Dios gracias, prosigo sin novedàd en la mia, que ofrezco à vuestra disposicion, saludando à todos con el mejór afecto, deseando que en su Comp(añi)a. mandes à tu m(a)s. ap(asiona)do. herm(an)o.

(Con letra de Jorge) Jorge

(Postdata al margen):

Querida Rita: quedo con el encargo que Usenia me hace, y procurarè evacuarlo. 


\section{(Otra postdata debajo de la firma):}

Que se haga la cosa quanto antes es sin duda lo mejor, conque procurare avivar lo posible.

Madrid 17 de Sept(iembr)e".

\section{4}

Francisco Soler de Cornellá a Nicolás Juan, Elche 17 de septiembre de 1763:

"Muy Señor mio y mi dueño con todo gusto recibo la de Vmd. alegrandome de su felis salud La de Mi Sra. Da. Maria Rita Mi Sra. Da. Rafaela y demas Señoras á cuyos pies me ofresco con mi tio Dn. Pedro y Hermanos que apresian y debuelven las expresiones á Vmds., quedando todos buenos para servirles en lo que gustasen mandarnos. Mis Primas llegarian ante anoche á Valencia donde las tendra Vmd. para quanto gustare mandarlas.

Mi Primo Dn. Joseph Molto a quien di parte de mi boda manifiesta á Vmds. y mi Sra. Da. Rafaela su gratitud en la adjunta Carta que me incluye para esta Señora, con motivo de cumplir sin retarda este encargo escrivo yo á mi Sra. Da. Rafaela dos Letras Suplico a Vmd. disimule este atrevimiento, y me permita tener respuesta de esta Señora si se dignase honrarme con sus Letras, que para mi seran de sumo apresio y estimasion.

La boda no podremos retardarla mucho pues por todo el mes de Noviembre se le acaba a mi hermano Dionis la licensia y me seria sensible que en dias de tanto regosijo para mi y mi casa nos faltasse su asistensia, a mas que siendo este asumto de mi tan solicitado y que tanto lo deseo passo las horas por años, y teniendolo todo prevenido, y que lo poco que falta dentro de este mes y el que viene parte, se concluira todo espero mereser á $V m d$. el favor de que no aya retarda alguna.

á Bernardo di las memorias de parte de Vmd. quien las debuelve, y no ocurriendo otro particular se servira Vmd. ponerme á los pies de Mi Sra. Da. Rita y demas Señoras y mandarme asegurado de mi verdadero imutable afecto con el que ruego á Dios g(uar)de. á Vmd. m(ucho)s. a(ño)s. Elche y 7 bre 17 de 1763

B.L.M. de Vmd. su mas Af(ect)o. Ap(asiona)do. ser(vid)or. que de corazon le estima Franco. Soler de Cornellá.

Si Vmd. me lo permite y de ello no tuviere inconveniente passare un dia de esta sig(uien)te. semana aunque sea de noche a tener el gusto de ponerme á los pies de las Señoras y dar á Vmd. un abrazo, aunque sea de noche por evitar cumplimientos y etiquetas si las puede aver.

Sor. Dn. Nicolas Juan". 
Francisco Soler de Cornellá a Rafaela Juan Ximenes de Urrea, Elche 17 de septiembre de 1763:

\section{"Señora.}

Muy Señora mia, y de mi mayor estimasion; mi Primo Hermano Dn. Joseph Moltó gozoso de nuestro tratado enlase de que le di quenta, me encarga dirija a poder de Vmd. la adjunta carta en la que la rinde las devidas grasias por la dignasion de Vmd. de admitirme por su siervo con tan distinguido caracter; esta devida resolusion de mi Primo me hase salir de la inacsion culpable en que estava sosobrando entre los temores de herrar en esta parte; confio disimulará Vmd. este mi atrevimiento, y como nasido de mi perpetuo amor, é indeleble cariño no lo estrañara pues ya en el Orito la signifique quanto deseava ver letra de Vmd. con este motivo ratifico á los pies de Vmd. mi voluntad, mi afecto, y todo mi corason que la estima y ama y amara perpetuamente, y no ocurriendo otro particular deseo continue Vmd. con la mas robusta salud, con mi Sra. Da. Rita y demas Señoras á cuyos pies me ofresco, quedando yo con el tio, y los Hermanos buenos, quienes hasen á Vmd. muy particulares expresiones de su cariño; interim me dispensa Vmd., sus dulses y apetesibles preceptos ruego á Dios dilate á Vmd. por muy felises años la vida como lo deseo para mi consuelo. Elche y 7 bre 17 de 1763 .

Señora:

A los pies de Vmd. su mas rendido y oblig(ad)o. siervo que de corason la adora

Franco. Soler de Cornellá

Sra. Mi Sra. Da. Rafaela Juan".

\section{6}

Joseph de Puigmoltó y Ortiz a Rafaela Juan, Onteniente 14 de septiembre de 1763:

"On(tenien)te. y 7 bre. 14 de 763

Muy Sra. mia; mi primo Dn. Fran(cis)co. Soler, (a quien estimo mucho,) me comunica la gustosa noti(ci)a. de haver puesto su atencion, en las concurrentes apre(cia)bles. circunstan(ci)as. de Vm. y merecer el distinguido Honor, de haverle Vm. admitido en su servicio: Y siendo tan interesado en tan superior gusto, impele 
mi recono(ci)da. obliga(ci)on. hasiendo a Vm. las mas respetosas Expre(sio)nes. de hagradesim(ien)to. en las que me acompañan mis Hijos, sirviendose $\mathrm{Vm}$. el pasarlas a todos los Sres.: Y repitiendome a los de Vm. pido a la Divina G(uar)de. a Vm. m(ucho)s. a(ño)s.

B.L.P. de Vm. con reconosim(ien)to. su ob(liga)do. cer(vi)dor.

Dn. Jh. de Puigmoltó y Ortiz

Mi Sra. Da. Rafaela Juan".

Francisco Soler de Cornellá a Nicolás Juan, Elche 20 de septiembre de 1763:

"Muy Señor mio y mi Dueño, recibo la de Vmd. con gusto, celebrando su mantenida salud y la de mi Sra. Da. Rita, mi Sra. Da. Rafaela y demas Señoras á cuyos pies me ofresco como mi tio Dn. Pedro y hermanos quienes quedamos sin novedad para quanto Vmds. quisieren mandarnos.

De sumo gusto me sera ver letra de Mi Sra. Da. Rafaela, por lo que si el Jueves meresiese su respuesta lo estimare muchisimo pongame Vmd. á sus pies con mil expresiones de mi afecto y digala, que el sabado sin falta por la tarde ago quenta de estar en essa ciudad.

en el mismo correo que Vmd. me avisó, le escrivi al Amigo Dn. Cepriano, y a las Primas Da. Margarita y Da. Maria Antonia La Religiosa.

De Dn. Cepriano tuve respuesta el mismo correo, pero de estas Señoras todavia no la he tenido, y como ya son pasados tres correos; estoi con cuidado no se ayan estraviado las cartas, pues etiqueta ni quexa conmigo estoi seguro no tienen de que fundarla, no obstante estimare que con disimulo indage Vmd. que ay en esto, y me avise.

no ocurre otro particular reciba Vmd. mil expresiones del tio y Hermanos y paselas de parte de todos a Mi Sra. Da. Rita y demas Señoras, interim quedo con todo afecto rog(an)do. á Dios g(uard)e. á Vmd. m(ucho)s. a(ño)s. Elche y 7 bre 20 de 1763.

B.L.M. de Vmd. su mas afecto y obligado serv(ido)r. y Amigo.

Franco. Soler de Cornellá.

Sor. Dn. Nicolas Juan". 


\section{Cara A:}

Borrador de una carta de Maria Rafaela Juan Ximenes de Urrea a Dn. Joseph de Puigmoltó, Alicante 22 de septiembre de 1763. Está escrito de puño y letra de Nicolás Juan:

"Muy Sr. mio recibo con todo aprecio las expre(sione)s. que á Vm. meresco, en el asumpto de mi boda con el Sor. Dn. Fran(cis)co. Soler de Cornellá; assegurandole que siempre desearemos ocasiones de complaser á Vm. y q(u)e. Dios le g(uard)e. m(ucho)s. a(ño)s. Ali(can)te. 22 de 7 bre. de 1763

B.L.M. de Vm. su m(a)s. af(ec)ta. serv(ido)ra.

Ma. Raf(ael)a. Juan Xim(ene)z. de Ur(rea).

Sr. Dn. Jph de Puig Moltó".

\section{Cara B:}

Borrador de una carta de Maria Rafaela Juan a Francisco Soler de Cornellá sin fechar. Escrito de puño y letra de Nicolás Juan:

"Muy Sr. mio: Recibi con grande agrado la carta de Vm. estimando las exp(resione)s. que le meresco a las que corresponde mi cincera gratitud como es debido, y assimismo a las de los Señores tio Dn. Pedro y H(erma)nos.

Ya escrivió a Vm. mi P(adr)e. el motibo de retardar yo esta y tambien respondió sobre la venida de Vm. de ¿embozo?, y q(uan)do. se determine venir será bien que $\mathrm{Vm}$. trayga la piocha q(ue). me remitio mi tio, y el adrezo, y demas, que Vmd. tenga prompto - pues dessean verlo algunas Parientas, que será razon darlas este gusto, y en la (ilegible) q(ue). Vm. trayga se podra ir trabajando - y no perder tiempo.

En todos (ilegible) complaser a Vmd. y q(ue). Ie g(uard)e. Dios m(ucho)s. a(ño)s".

19

Francisco Soler de Cornellá a Rafaela Juan Ximenes de Urrea, Valencia 18 de octubre de 1763:

"Señora.

Muy Scñora mia y de toda mi estimasion recibo con sumo gusto la favoresida de Vmd. celebrando su felis salud y la de Mi Sra. Da. Rita y demas Scñoras á cuyos pies me repito estimando sus memorias, y manteniendome sin novedad con Donis y las Primas que apresian y debuelven á Vmd. sus expresiones. 
el Viernes inmediato sin falta ago quenta de salir para Elche con todos los encargos de aqui Los que no podran estar el dia de San Rafael á los pies de Vmd. como tenia deliberado para que en dia de tanta celebridad para mi tuviese Vmd. esta pequeña demostrasion de mi afecto pero á lo menos procurare luego que llegue á Elche remitirles con la mayor brevedad para que pueda Vmd. disponer quanto antes gustare los vestidos que yo por mi parte no me descuidare en reglar lo que resta á disponer en Casa que es muy poco.

no tenga Vmd. que escrivirme á esta que á mi arribo á Elche ya la escrivire yo á Vmd. para tomar sus ordenes, y tanbien el permiso de poder pasar á verla aunque no sea mas de una noche, pues ya se hara Vmd. cargo quanto lo deseo, y quan escasamente he podido lograr este bien en un año, enfin ya me ago cargo que la pasiensia ha de suplir el merito que falta, aunque no afecto, con el mayor puede Vmd. estar asegurada tiene mi corason á sus pies y que como arbitra absoluta de mi voluntad ha de disponer de mi como y quando gustare que este sera mi mayor gusto. no se olrese otra cosa particular paselo $\mathrm{Vmd}$. bien mientras yo repitiendome á sus pies ruego á Dios la g(uar)de. m(ucho)s. a(ño)s. Valencia y 8 bre 18 de 1763.

Me alegrare que el Sor. Dn. Nicolas se restituya bueno del Ondon dele Vm. mis memorias, y digale que en llegando á Elche le escrivire.

Señora

A los pies de Vmd. su mas rendido ser(vid)or. que con todo el corason la estima. Franco. Soler de Cornellá.

Señora Mi Señora Da. Rafaela Juan y Ximenes de Urrea".

Despacho expedido por el Administrador de Rentas Generales de la Real Hacienda y dirigido a la Real Aduana de Valencia acreditativo del pago de los derechos de determinadas mercancías que Francisco Soler de Cornellá remitía a Nicolás Juan, fechado en Valencia el 22 de octubre de 1763:

"Año de 1763, Reyno de Valencia, $\quad$ Numero 3978

\section{Para la Real Aduana de Valencia \\ ADMINISTRACION DE RENTAS GENERALES}

a cuenta de la Real Hacienda

Guardas de las Rentas de Diezmos, y Puertos Baxos, sus Agregados, y la del segundo dos por ciento, y demàs Generales, dexad passar à D. Fran(cis)co. Soler, de Elche que saca de esta Real Aduana para d(ic)ha. villa de transito p(ar)a. remitir á 
Alicante y entregar a D(o)n. Nicolas Juan, un Juego de peto, paletina, delantal, y lazos de marli con flores, unas guarniciones de blondina y seda p(ar)a. bata, una manteleta de encaje negro felpado, quatro $\mathrm{p}(\mathrm{a}) \mathrm{res}$. medias de seda blancas con quadrillos bord(ado)s., ocho p(a)res guantes de seda blanchos y negros, y tres cajas de lozas comp(ra)do. de Ant(oni)o. Areco, y ciento veinte y una var(a)s. texidos de sedas fab(ri)ca. de esta ciu(da)d. De cuyos gen(ero)s. consta est(a)r. pag(ado)s. los d(e)r(ech)os. á est(a)s. R(en)tas. excepto los tex(id)os. que no lo deven. Y de este Desp(ach)o. se ha de tom(a)r. la raz(o)n. p(o)r. el S(eño)r. cont(ad)or. de est(a)s. $\mathrm{R}(\mathrm{en})$ tas. y reglo. el fiel de la P(uer)ta. del R(ea)l. valga quince dias. Val(enci)a. y Oct(ub)re. v(ein)te. y dos de 1763

\author{
Por el Adm(inistrad)or. g(enera)l. \\ Helguero \\ Tome la Razon \\ (ilegible)".
}

Bernardo Juan Santacilia a María Rita Ximénez de Urrea, Elche 25 de octubre de 1763:

"Q(ueri)da. M(arí)a. Rita: me alegraré q(ue). en compa(ñía). de Nicolas y las chicas lo pases bien; Yo continuo a D(io)s. gr(acia)s. bueno p(ar)a. servirte.

tengo animo de regalarle a la Rafaela un vestidillo de seda ya sea p(ar)a. cstrado, o p(ar)a. Yglesia o una bata, y p(ar)a. azertarlo me ha parecido hermanablemente preguntarte $\mathrm{q}(\mathrm{ue})$. es lo $\mathrm{q}(\mathrm{ue})$. mas convendrá $\mathrm{p}(\mathrm{o}) \mathrm{r}$. si podemos assi cscusar a su Padre de algun gastico; discurro q(ue). no te ofenderas de esta confianza y q(ue). me darás tu aviso, repitiendoles a las chicas mis m(emoria)s. como a Nicolas a q(uie)n. no dirijo esta $\mathrm{p}$ (or)q(uc). rezelo $\mathrm{q}(\mathrm{ue})$. esta fuera, y tu mandame $\mathrm{q}(\mathrm{uan}) \mathrm{to}$. sca de $t u$ mayor agr(ad)o. mient(ra)s. r(ueg)o. a D(io)s. te g(uard)e. m(ucho)s. a(ño)s. Elche y 8 bre 25 de 1763

tu her(ma)no. q(ue). m(a)s. te est(im)a. y t(u)s. P(ie)s. B(esa).

Ber(nar)do.

Q(ueri)da. Her(ma)na. M(arí)a. Rita". 
Bernardo Juan Santacilia a María Rita Ximénez de Urrea, Elche 29 de octubre de 1763:

"Q(ueri)da. Rita: en conformidad de lo q(ue) me insinuas en tu ultima: escrivo p(o)r. el correo de oy a Valencia p(ar)a. q(ue). se tomen la(s) 17 V(ara)s. de mué negro, cuyo encargo hago a las SS(eñor)as. Marcos q(ue). discurro tendrán gusto p(ar)a. eligirle; cuyo aviso te doy p(ar)a. q(ue). podamos aprovechar qualq(uie)r. ocasion q(ue). se ofresca p(ar)a. conducirle yá sea por sujeto de essa ciud(a)d. o de esta Villa; esperando q(ue). me darás noticia quando te se proporcione medio q(ue). le trayga, respeto $q(u e)$. Juaquin Perpinian $q(u e)$. yo confiava $q(u e)$. podria serlo se ha puesto yá en camino, y por lo tocante a los demás recados discurro $q(u e)$. $p(o) r$. estos passes tendremos entretanto ocasion de tomarles.

El nobio llegó bueno y con todos sus miriñaques haviendole retardado su viaje las muchas lluvias q(ue). assí en Val(enci)a. como en el camino sc experimentan, de $q(u e)$. no dudo dará $\mathrm{p}(\mathrm{o}) \mathrm{r}$. el correo de oy aviso.

Dale mis m(emoria)s. a Nicolas como tambien a las chicas esper(an)do. q(ue). todos me mandeis q(uan)to. sea de v(uest)ro. mayor satisf(accio)n. y agr(ad)o. al $\mathrm{q}($ ue). me reitero deseando q(ue). $\mathrm{D}$ (io)s. te $\mathrm{g}$ (uard)e. m(ucho)s. A(ño)s. Elche y 8 bre 29 de 1763

tu her(ma)no. q(ue). m(a)s. te est(im)a. y t(u)s. P(ies). B(esa).

Ber(nar)do.

Q(ueri)da. her(ma)na. D(oñ)a. M(arí)a. Rita".

23

Francisco Soler de Cornellá a Nicolás Juan, Elche 29 de octubre de 1763:

"Muy Señor mío y mi dueño: celebrare que Vmd. se mantenga bueno, yo llegue de Valencia Jueves por la tarde con muy mal camino, desde Valencia asta aqui no ha cessado de llover discurra Vmd. que tal estaran los caminos, por ultimo ya hemos salido de estos quehaseres y nos vamos llegando al deseado puerto, que con esta esperansa nada acobarda y todo se Ileva bien. Ya dije á Vmd. que á mi hermano Dionis le es presiso á principios de D(iciem)bre. marchar á su cuerpo, por lo que he de mereser á Vmd. la singular finesa de q(ue). proporsione Vmd. las cosas, para que por todo Noviembre sea la funcion de boda, por que de otra forma no tendremos el gusto de que este hermano se pueda hallar, que yo por mi parte lodo lo prevendre apunto dentro de quinse dias lo mas largo. 
ya digo á mi Sra. Da. Rafaela que un dia de estos permitiendolo Vmd. passaré á essa ciudad a ver á esta Señora y conferenciar con Vmd. algunas cosillas presisas, una de ellas es sobre asumto de cartas matrimoniales, Vmd. de aqui á la vista puede pensar si quiere que se agan antes de la boda ó despues, para que me diga aquien devo en todo lanse dar los poderes que son nesesarios. Y no ocurricndo otro particular ratifico á Vmd. los deseos de servirle a cuya obediencia quedo rog(an)do. á Dios leg(uar)de. m(ucho)s. a(ño)s. Elche y 8 bre 29 de 1763.

B.L.M. de Vmd. su seg(u)ro. Af(ec)to. servidor

Fran(cis)co Soler de Cornellá

Sr. Dn. Nicolas Juan".

Pedro, Obispo de Orihuela, a Nicolás Juan. Orihuela 19 de noviembre de 1763:

"Muy S(eñ)or. mio: satisfaciendo mi verdadera gratitud â la muy atenta de V. de 17 del corr(ien)te. en q(u)e. se sirve participarme el tratado casamiento de su hija, mi S(eño)ra. D(oñ)a. María Rafaela con el S(eño)r. D(o)n. Fran(cis)co. Soler de Cornella; repito â ambos $S($ eño)res. y â $V$. como no menos interesado la mas cxpresiva enhorabuena, haviendose anticipado al precepto de $\mathrm{V}$. mi deseo de complacerle en el particular del Breve, que tengo concedido ya desde luego que se me pidio por parte de d(ic)ho. cavallero con quanto fuesse dispensable, atendidas las distinguidas, y lucidas circunstancias de ambos contrayentes; repitiendome con este motivo â la obediencia y obsequio de V. con toda voluntad, segun q(u)e. ruego â la Divina gu(ard)e. su Vida m(ucho)s. a(ño)s. orihuela y Nov(iembr)e. 19 de 1763

BLM de V. su mayor ser(vi)dor. y ca(ilegible).

Pedro Ob(is)po. de Orihuela.

S(eñ)or. D(o)n. Nicolas Juan".

\section{5}

Francisco Soler de Cornellá a Nicolás Juan, Elche 19 de noviembre de 1763:

"Muy Señor mio y mi dueño: remito el adjunto despacho inclusa una nota de lo que se deve practicar en la justificasion de la libertad de Mi Sra. Da. Maria Rafaela, el qual se servira Vmd. entregar en sus manos á este Vicario pedaneo, con la Carta que es de mi Hermano Leonardo para que no nos detenga: de Su Iltma. tuve 
respuesta muy atenta disiendo nos dispensara todo lo que sea dable, con que estamos bien. ya me dise mi Sra. Da. Maria Rafaela que los vestidos se han cortado, y que se va adelantando lo que falta lo que celebro pues de esta forma tal ves el dia de San Nicolas podria ser el desposorio; el poder para cartas esta semana que entra le llevare yo. y no ocurriendo otro particular quedo de Vmd. rog(an)do. á Dios Le g(uar)de. m(ucho)s. a(ño)s. Elche y 9 bre. 19 de 1763.

\author{
B.L.M. de Vmd. Su Afe(c)to. y oblig(a)do. ser(vid)or. \\ Fran(cis)co. Soler de Cornellá \\ Sor. Dn. Nicolas Juan".
}

\title{
26
}

Francisco Soler de Cornellá a Nicolás Juan, Elche 9 de diciembre de 1763:

"Muy Señor mio y mi dueño: deseo que Vmd., y todas las señoras con frasquito logren felis salud, cuyo beneficio disfruto con mi tio y Hermanos que hasen á Vmds., mil finas expresiones, celebrando el gusto del arribo de Jorge, tan aliviado como me disen que viene grasias á Dios de sus quebrantos.

el Lunes pasado imbie un criado de Casa por los Cajones (que me trajo) con él escrivi á Mi Sra. Da. Maria Rafaela incluyendole dentro de la Carta el breve para nuestro desposorio, y aunque confio que no se haya perdido un papel tan notable como este, porque el moso es de confianza y sabia lo que llevava, con todo me tiene con cuidado no haverme trahido él respuesta del recibo de Mi Sra. Da. Maria Rafaela, ni haverla tenido en este Correo, por lo que he de dever á Vmd. se sirva desirme si este papel llegó, ó, no en la carta que imbie con el dicho Moso para poderme sosegar en el cuidado en que estoi.

Ya sabe Vind. que dias hase le tengo manifestados los perjuisios que se me estan siguiendo de la retarda de la boda, y que me hera presiso celebrarla antes de Navidad, esto mismo le encargue á frasquito manifestase á Vmd., y en el mismo correo se lo escrivi á mi Sra. Da. Rafaela suplicandola hisiese presente á Vmd. que quando no pudiese ser el Dia quinse por lo inmediato al arribo de Jorge, a lo menos que fuese el dia dies y nueve q(ue). es de este Lunes en ocho dias, en cuyo intermedio tiene Jorge suficiente tiempo para repararse de la fatiga del camino, de cuyo asumto tampoco me contestó directamente Mi Sra. Da. Rafaela, de lo qual, y de el modo cono se explico Bernardo delante de frasquito reselo si Vmd. querra diferirlo para despues de fiestas; en qualquiera casso no puedo yo dexar de venerar como devo esta, y qualquiera otra resolusion de Vmd., pero me es presiso haserle presente, que hallandose mi hermano Leonardo con la presision de marchar á otro dia de Navidad 
á su Curato que es el dia que le queda del mes que tiene presision de estar alli á otro dia, tendria yo el sentimiento de que este Hermano no me asistiese, por lo que suplico á Vmd. encarecidamente que quando no quiera atender á los perjuicios que se me estan siguiendo, á lo menos por dicho mi hermano a quien tan sensible le ha de ser el no asistir en la funcion se digne disponer las cosas de forma que dicho dia dies y nueve llegue aqui esta Señora, pues de lo contrario aseguro á Vmd. causará en mi tio, y en todos los de esta de Vmd. un sumo disgusto; sobre todo Vmd. es muy dueño de disponer lo que gustare que aqui no queremos mas de lo que sea de la mayor satisfacsion de Vmd., y de Mi Sra. Da. Rafaela, á cuyos pies como al de todas las otras Señoras me ofreserá Vmd. con todo respeto dando mil saludos a frasquito, y no ocurriendo otro particular quedo muy de Vmd. $\operatorname{rog}(a n) d o$ á Dios leg(uar)de. m(ucho)s. a(ño)s. Elche y D(iciem)bre 9 de 1763.

B.L.M. de Vmd. su Afecto y seg(u)ro servidor

Fran(cis)co. Soler de Cornellá

Sr. Dn. Nicolas Juan".

\section{7}

Francisco Soler de Cornellá a Nicolás Juan, Elche 10 de diciembre de 1763:

"Muy Señor mio y mi dueño: en consequencia de la de Vnd., haviendo conferido con Bernardo hemos resuelto sea la funcion el Domingo 18 de los corrientes, pues el ser los dias que se les subsiguen al Jueves, y Lunes ayuno de precepto les hase algo incomodos, por lo que nos ha paresido el Domingo mejor dia, que aunque es dia de precepto el tener Oratorio en casa Vmd. facilita el embaraso que pudiera haver de la Misa; por este motivo y porque los cosineros no esten aqui tantos dias detenidos no imbiare la galera asta cl miercoles, que hira sin falta para que en los dias Jueves, Viernes, y Sabado prevengan los trabajos, y el Sabado bolvera á hir para traer Cofres, y demas que Vmd. mande.

deseo que Mi Sra. Da. Rita, Mi Sra. Da. Maria Rafaela y demas Señoras con frasquito lo pasen bien ofrescales Vmd. mis devidos respetos y a Jorge mil saludos, y que acabo de recibir una suya; Ygualmente mi tio y Hermanos han apresiado mucho las memorias de Vmd. y las Señoras á quienes las debuelvo con todo afecto, y Yo quedo con el mismo rog(an)do. á Dios le g(uar)de. m(ucho)s. a(ño)s. Elche y $\mathrm{D}$ (iciem)bre. 10 de 1763.

B.L.M. de Vmd. su seg(u)ro. Af(ec)to. y oblig(a)do. ser(vid)or.

Fran(cis)co. Soler de Cornellá

Sor. Dn. Nicolas Juan". 
Borrador escrito por Nicolás Juan con la lista de personas a quienes se debía dar cuenta de la boda de su hija María Rafaela. Todos los nombres están tachados:

"P(ar)a. la boda de Ma. Raf(ael)a. se ha de dar la cu(en)ta. sig(uien)te. A mis herm(ano)s. Cip(rian)o., Man(uel)a., Marg(ari)ta., Jorge, Ber(nar)do., Mi H(ij)a. M(ari)a. Theresa, la Condesa de Berbedel, D(oñ)a. Ant(oni)a. Ivarra. Dn. Enrique Clavero, el Marques de Lazan, Dn. Mig(ue)l. Muñoz de Pamplona, la Marquesa de Villalon, el Marques de Albayda, el Marques de Sn. Jph., el Baron de Escrich, el Conde de Organya., Dn. Mig(ue)l. (ilegible), Da. M(ari)a. Ant(oni)a. la figuera, la Varonesa de Sangarren, Dn. Manuel Villalba, D(oñ)a. Mariana (¿Pucyo?), la de Albayda, Postigo, la Marq(ues)a. de Ayerbe, Dn. Luis Urrios, Da. Marg(ari)ta. Lopez, D. J(ose)ph. Marin, la de Torrellano y el Conde, el Marques de Arneba, el Conde de Carlet, y a sus Herm(ano)s".

El Conde de Torrellano a Nicolás Juan, Elche 20 de septiembre de 1763:

"Muy Sr. mio. con la estimada de Vm. de 17 del que sigue, entiendo el nuevo estado de mi Sra. Da. Maria Raphaela, pretende con la devida aprovacion de Vm. tomar con Dn. Fran(cis)co. Soler de Cornellá, cavallero de las circunstancias de Nobleza y demas que Vm. me significa, cuyo pensamiento haviendo manifestado a la Condesa mi muger segun el encargo de $\mathrm{Vm}$. de un acuerdo aprovamos como corresponde hesta acceptable resolucion, que siendolo de las satisfacciones de Vm. nada mas tenemos que apetecer, y si solo rogar a Dios Ntro. Sr. por los favorables efectos que pide el estado, y repetirme al servicio de Vm. y Mi Sra. su muger como siempre con desseo de que g(uar)de a ambos, su importante vida, los m(ucho)s. a(ño)s. que desseo. Elche y 7 bre 20 de 1763.

B.L.Mo. de Vm. su mas afecto ser(vid)or.

El Conde de Torrellano

Sr. Dn. Nicolas Juan". 


\section{Cara A:}

El Marqués de Arneba probablemente a Nicolás Juan, Orihuela 20 de septiembre de 1763:

"Muy Sr. mio y Amigo: resivo la de Usia en la que se sirve darme quenta de el tratado de boda de mi Señora Da. Rafaela con Dn. Fran(eis)co. Soler, cuio asumpto me es de mucha satisfaccion, pues me constan las completas sircunstancias que concurren en este caballero. Resiva Usia los mas expresivos plasemes, los q(u)e. pasarâ higualm(en)te. a mi Señora Da. Rita, Señora Nobia, y demas Señoras ofresiendo mi respeto a sus pies con finas memorias, y enorabuenas a mi hermana, las que resivirâ Usia higualm(en)te. y repitiendome a su obediencia, ruego a N(uest)ro. S(eñ)or. g(uard)e. a Usia m(ucho)s. a(ño)s. Orihuela 20 de Sep(tiem)bre. de 1763.

B.L.M, de Us. su m(a)s. af(ec)to. y Seg(u)ro. ser(vid)or.

El Marques de Arneba".

\section{Cara B:}

M. Sannazar a Nicolás Juan:

"Padre y Muy Sor. mio: selebro la salud de Vm. la M(adr)e. y Herm(an)as. de cuyo beneficio logran los tios, y Nosotros repitiendonos todos, a la disp(osici)on. de Vinds.

Nosotros hemos venido a esta de Callosa por unos dias, hemos visto los toros y aora desp(ue)s. de dibertirnos, esmenester cuidar de lo q(u)e. es N(ues)tro. A Rafacla q(u)e. tenga pasiencia y q(u)e. empiese a llebar la cruz del Matrim(oni)o. Nos repetimos a Vmds. con las veras de N(ues)tro. Cariño con el q(u)e. deseo q(u)e. N(ues)tro. Señor gu(ard)e. a Vm. en Comp(añi)a. de todos m(ucho)s. a(ño)s.

B.L.M. de Vm. su m(a)s. af(ec)to. Hijo

\section{Sannazar}

Aqui hay este Domingo que viene comedia, representada por unos farcantes mui buenos, vengan Vm. y se dibertiran, pues pueda ser ayga Baquitas, y Hay mui buenos fuegos". 
Maria Josepha de Castellví y Escrivá a Maria Rita Ximénez de Urrea, Valencia 21 de septiembre de 1763:

"Prima y querida mia siento tu indisposicion, y celebrare te recobres quanto antes de tu fluccion que la discurro ocasionada de la estacion. Celebro la noticia que me participas del tratado de Boda de tu Hija Maria Rafaela con Dn. Fran(cis)co. Soler de Cornellà, pues siendo de tu aprobacion nodudo serà con todos los cabales que Maria Rafaela se merese, à la que le deseo la mayor felicidad en su nuevo estado, como que tu me mandes quanto sea de tu mayor satisfaccion, à mi Primo retorno sus expreciones con todo afecto quedando tuya para quando gustares mandarme, rogando â Dios te me g(uar)de. los m(ucho)s., y felices a(ño)s. Valencia, y setiembre à 21 de 1763.

querida mia, pase a Maria Apolonia tu encargo, la que estima tu confiansa, y selebra este tratado, y manda te diga que nada tiene que añadir, sindo de tua aprobasion que selebrasle y dante muchas enorabuenas, y saluda a tus hijas, como io, y manda,

Te B.L.M. tu prima, amiga y maior serbidora,

Maria Josepha de Castellví y Escriva

A mi querida Prima, y Señora Dña. Maria Rita Gimenes de Urrea”.

Manuela Juan Pasqual a Nicolás Juan, San Felipe 21 de septiembre de 1763:

"Q(ueri)do. h(erma)no. recibo la tuia y a su contenido devo desirte q(ue). siempre he creido entrariamos en la quenta general Cipriano, Margarita, y io, como uno de los compredidos en ella, te doy la enorabuena, y asimismo a Rita con muchas expreciones, a esta y niñas, J(acin)to.* estima las huestras, y las retorna con el maior afecto, con el que os deseo las maiores satisfasiones, y quedo r(ogan)do. a $\mathrm{D}(\mathrm{io}) \mathrm{s}$. te g(uar)de. m(ucho)s. a(ño)s. S(a)n. Felipe y 7 bre. a 21 de 63

tu h(erma)na. q(ue). m(a)s. te estima

Manuela

Q(ueri)do. h(erma)no. Nicolas". 
Isidoro a Nicolás Juan, Cartagena 21 de septiembre de 1763:

“Cartag(en)a. y S(e)p(tiem)b(re). 21 de 1763.

Mi Q(uerid)o. Dueño y Am(ig)o. tu estimada de 18 del presente deja a mi reconosida ley como a Anica Juanico y demas gustosos tanto por las favorables noticias de tu salud la de Madama y Señoritas quanto por lo que yninuas un punto a haberse pedido á mi Sra. Da. Rafaela, Dn. Fran(cis)co. Soler por lo que damos, y resevimos, como tan ynteresados en las satisfasiones de Unos y de otros, las correspondientes enorabuenas $p(o) r$. tan asertada elexion; deseosos de q(u)e. en tan amable union esperimenten largos años de Vida con colmo de felisidades y que a li a Madama y demas les suseda lo mismo, teniendo s(iem)pre. presente n(uest)ra. ynmutable ley para Valerse de ella con sus frequentes presertos.

En este Correo a avido Cartas de las Alusemas en las que disen se mantenian todos buenos, y que saldrian de alli p(ar)a. continuar su comision luego; por lo que me persuado no tarden en bolber a esta el Armamento al que se le a agregado el Sptentrion que el otro dia partio para yncorporarse con ellos.

As un Cunplido de n(uest)ra. p(ar)te. a todas y a todos y manda

A tu afecto de veras

Isidoro

Q(uerid)o. mio Dn. Nicolas Juan".

\section{4}

Antonia Ibarra Santacilia a Nicolás Juan, Elche 27 de septiembre de 1763:

"Elche y Sette. 27 de 1763

Querido Hermano Dn. Nicolas: recibí la tuya de 11 del corriente la que no pude dar respuesta a tu Estimada por hallarse Feliz ocupado y ausente lo hago aora manifestando el regosijo que me cabe de la buena eleccion de Frasquito Soler pues las singulares prendas de Da. Rafaela a mas de lo distinguido de tu cassa por su Persona se merese la mayor estimacion; Yo la hago muy distinguida por lo que me favoreses en partisiparme la noticia de este enlace, te doy mil enorabuenas como a Da. Maria Rita 
acompañando Dn. Feliz con las mas expresivas esperando que nos tendreis en memoria para haser experiencia de nuestra voluntad y afecto con que descamos serviros quedando toda esta tu casa tuya rogando a Dios te g(uar)de. m(ucho)s. a(ño)s.

Quien de corason te es(tim)a. tu Hermana

Antonia Yvarra

Querido H(erman)o. Dn. Nicolas Juan".

El Conde de Carlet a Nicolás Juan, Valencia 30 de septiembre de 1763:

"Pariente Amigo, y Sor. mio: recivi su muy favorecida de 13 del que acava, con la apreciable noticia que se sirve Vs. noticiarme del tratado casamiento de mi Sra. Da. Rafaela con Dn. Francisco Soler de Cornellá, persona de las circunstancias que acreditan sus meritos; Y siendo de la aprobacion de V.S. es para mi la mayor satisfaccion.

Sup(li)co. me ponga á los $\mathrm{P}(\mathrm{ies})$. de mi Sra. Da. Maria Rita, y demas S(eñor)as. y V.S. me dispenze los preceptos de su mayor agrado.

Dios Gu(ar)de. â V.S. m(ucho)s. a(ño)s.

Valencia, y S(eptiem)bre. 30 de 1763

BLM de V.S. su mas seguro servi(d)or. y Pariente

el Conde de Carlet

$\operatorname{Par}($ ien)te. Am(ig)o. y S(eñ)or. Dn. Nicolas Juan".

\section{6}

La Baronesa de Sangarren a Maria Rita Ximenez de Urrea, Zaragoza 4 de octubre de 1763:

"Prima y $q(u)$ erida. mia, me es mui de mi estimacion, las expresiones $q(u)$ e. te merezco en la tuia, y en partiziparme el aber pedido, á la Parienta Da. Maria Rafaela, tu Hija el Sr. Dn. Fran(cis)co. Soler de Cornellá; y concurriendole las circunstancias 
de tu satisfaccion como me expresas, te doi la henorabuena deseandote todos los consuelos y satisfacciones q(u)e. te merezes; aras estas mismas expresiones de mi obligacion, á la Parienta y me mande: à mi Primo B.L.M. dandole la henorabuena, q(u)e. ya mi Hermano á tenido Carta suia, y esta mui gustoso de q(u)e. te halles con esta satisfaccion estimado à todo lo q(u)e. le favorezes;

Querida siento te halles con la flugsion q(u)e. me dizes q(u)e. es menester te cuides $=$ ya puedes considerar como puedo estar con mis ajes y desconsuelo: en todo caso no escuses el mandarme cuanto sea de tu agrado: Díos te g(uard)e. m(ucho)s. a(ño)s. Zarag(oz)a. y 8bre 4 de 1763.

Te B.L.M. tu P(ri)ma. Amiga y mas cierta serbidora

La Baronesa de Sangarren

P(ri)ma. y querida mia no puedes dudar de mi obligacion cuanto te deseo todos tus consuelos y asi no escuses el mandarme pues io siempre te soi mui tuia de corazon.

Pa(rien)ta. q(u)erida. mia Da. Maria Rita Ximenz de Urrea".

37

Luis Urries a Nicolás Juan, Zaragoza 4 de octubre de 1763:

"Primo Amigo y Querido mio:

Quedo sumamente agradecido â la memoria con que me favoreces participandome, como D(o)n. Fran(cis)co. Soler y Cornella te ha pidido á tu Hija y S(eñor)a. mi S(eñor)a. D(oñ)a. Maria Rafaela, lo que siendo de tu satisfaccion, lo es igualmente mia y deseo sea con toda felicidad, de que te doy mil enorabuenas.

Haras esta misma cspresion á mi Prima, quedando igualmente reconocido á su fineza; $y$ deseando emplearme en q(uan)to. fuese de su obsequio.

Mi hermano Hugo esta actualmente en la Corte, y este mismo Correo lc cscribo sobre este mismo Particular, como me prebienes, y no dudo, que sea de su mayor satisfaccion; y no ocurriendo otra cosa ruego a Dios te g(uar)de. m(ucho)s. a(ño)s. Zarag(oz)a. y 8 bre 4 de 1763.

tu primo q. mas te estima

Luis Urries y C(ilegible)

Mi Primo y S(eñ)or. D(o)n. Nicolas Juan". 
María Manuela de Villanueva y Urries a María Rita Ximenez de Urrea, Zaragoza 4 de octubre de 1763:

"Prima y Querida mia: Al recivo de la apreciable tuya corresponde mi affecto complacido por las noticias q(u)e. tu salud me conduce en compañia de tu Pariente cuya mano beso, ofreciendo â tu disposicion la q(u)e. me favorece, siendo igual la de Luis, $\mathrm{q}(\mathrm{u})$ e. a tus Pies queda; Y no dudando ver tan distinguidas las calidades del S(eñ)or. D(o)n. Fran(cis)co. Soler de Cornell, te repito la enhorabuena deseosa de q(u)e. Maria Rafaëla logre en este enlace, quantas satisfacciones son apetecibles, y a q(u)e. tengas el gusto de verla tambien empleada.

Mandame quanto gustes Ynterin pido a Dios te gu(ard)e. los a ̃N(o)s. de mi deseo: Zaragoza 4 de 8 bre de 1763.

q(ueri)da, P(ri)ma. siento mucho te alles molestada del destenple de cabeza y te deseo el entero alibio, al p(resen)te.. B.L.M. y ambos os repito mil enorabucnas, como tambien á M(ari)a. Rafaela a quien como á ti me ofrezco para serbiros;

te B.L.M. tu P(ri)ma. Amiga y Afecta serbidora

M(ari)a. Manuela de Villanueba y Urries

Prima y Q(ueri)da. mia D(oñ)a. Maria Rita Xim(ene)z. de Urrea".

La Marquesa de Albaida a María Rita Ximenez de Urrea, Valencia 4 de octubre de 1763:

"Prima y querida mia:

Rezibo tu Carta en la que me participas el ajustado casamiento de tu hija D(oñ)a. Maria Rafaela, con el S(eñ)or. D(o)n. Fran(cis)co. Soler de Cornellá, de lo que te doy la enhorabuena, quedando para servirte, y Rogando â Dios te gu(ard)e. m(ucho)s. a(ño)s. Val(enci)a. 4 de Octubre de 1763.

Querida mia, siento tu indisposicion de destenplanza de Cabeza q(ue). me dices padeces, y te deseo todo alivio repitiendome para serbirte.

T(e). B.L.M. tu P(ri)ma. Amiga y serbidora

La Marquesa de Albayda

Mi S(eño)ra. D(oñ)a. Maria Rita Ximenez de Urrea". 
El Marqués de Albaida a Nicolás Juan, Valencia 4 de octubre de 1763:

"Mui S(eñ)or. mio, y mi Pariente: Rezibo la Carta de V.s. de 24 de el pasado, en que V.s. me participa el tratado casamiento de mi S(eño)ra. D(oñ)a. Maria Rafaela Juan, y Ximenez de Urrea su hija de V.s. con el S(eñ)or. D(o)n. Francisco Soler de Cornellá, de que doy â V.s. la enhorabuena, suplicandole ponga mi respeto â los pies de mi S(eño)ra D(oñ)a. Rita. Y quedo de V.s. con iguales deseos de complazerle.

Dios gu(ard)e, â V.s. m(ucho)s. a(ño)s. como deseo. Valencia, y Octubre â 4 de 1763.

B.L.M. de V.S. su Pa(rien)te. i m(ay)or. Se(rvid)or.

El Marques de Albaida.

S(eñ)or. D(o)n. Nicolas Juan".

\section{1}

Joseph Marín y Gurrea a Nicolás Juan, Zaragoza 5 de octubre de 1763:

"Mui S(eñ)or. mio, Par(ien)te. y Amigo.

Por el Correo de oy recivo la estimable Carta de VS. con F(ec)ha. del 24, pasado sel(iembr)e. en la $q(u)$ e. le merezco la afectuosa attencion de participarme haver el S(eño)r. D(o)n. Fran(cis)co. Soler de Cornella pedido en matrimonio â mi S(eñor)a. y Par(ien)ta. D(oñ)a. Rafaela, y siendo como VS. me dize un Cavallero de distinta y esclarecida naturaleza con los demas aderentes, q(u)e. hacen apreciable la Proposicion, celebro esta occasion de manifestar a VS. la satisfaccion q(u)e. puede apetecer el deseo conq(ue). vivo de todas las de VS. y de la Par(ien)ta. mi S(eñor)a. $\mathrm{D}$ (oñ)a. Rita, â cuios $\mathrm{P}$ (ie)s. tributo mi respetoso rendimi(en)to. con igual expresion â la q(u)e. hago a VS. la q(u)e. ha escrito â mi muger, y no tenia VS. q(u)e. haverse cansado en escrivirme separadamente pues entre Nosotros era ocioso cumplimiento: tendré el mayor gozo de q(u)e. llegue â efecto este tratado, como q(u)e. â cl sigan las mas prosperas consequencias, en cuia finalizacion de asunto daré â VS. la cnhorabuena, y entretanto la recivirá VS. de Marg(ari)ta.

Dios g(uard)e. â V.S. m(ucho)s. a(ño)s. como deseo. Zarag(oz)a. 5 Oct(ubr)e. de 1763.

B.L.M. de V.S. su P(arien)te. y seg(ur)o. Am(ig)o.

Jph. Marín y Gurrea

S(eñ)or. D(o)n. Nicolas Juan". 
Miguel Muñoz de Pamplona a Nicolás Juan, Zaragoza 5 de octubre de 1763:

"Muy S(eñ)or. mio, y mi estimado tio: con el maior gusto recivo la favorecida de Vs. en que se sirve participarme el tratado casam(ien)to. de mi Prima y S(eño)ra. D(oñ)a. Maria Raphaela, con el S(eñ)or. D(o)n. Francisco Soler de Cornellá, de que doi a Vs. mil enorabuenas, deseando que de este enlace resulten â Vs. las mas cumplidas satisfacciones, como tan interesado en todas ellas.

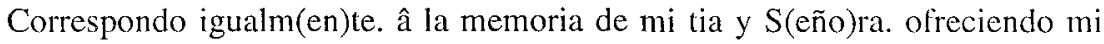
rendimiento â sus pies, â los q(u)e. se repite Miguelito, que dá â V.s.s. cariñosos abrazos.

Y suplicando â Vs. disponga â su arbitrio, de mi fino afecto, y pronta obedd(ienci)a. ruego â N(uest)ro. Señor gû(ard)e. â Vs. los m(ucho)s. a(ño)s. que des(e)o. Zarag(oz)a. 5 de Oct(ubr)e. de 1763/.

B.L.M. de Vs. su mas af(ect)o. sob(ri)no. y obl(igad)o. serv(ido)r.

Miguel Muñoz de Pampa.

Mi tio, y S(eñ)or. D(o)n. Nicolas Juan/"'.

\section{3}

Miguel (ilegible) a Nicolás Juan, Zaragoza 5 de octubre de 1763:

"Primo y Amigo y S(eño)r. mio no me toca sino el celebrar y darme mil enorabuenas de la colocación de la parienta con el S(eñ)or. D(o)n. Francisco Soler tan destinguido en su Nobleza como las circunstancias de el nuebo enlace y asi se las repito mui a mi satisfaccion expresando lo mismo a la Prima a quien me repito a sus inescusables ordenes deseando ambos las satisfaciones de su maior agrado. $D$ (io)s. g(uard)e. a Vs. los años que deseo Zaragoza y octubre a 5 de 63.

B(es)a. la mano de Vs. su mas cierto servidor amigo y $\mathrm{pr}(\mathrm{im}) \mathrm{o}$.

Miguel (ilegible)

Primo Amigo y S(eño)r. Dn. Nicolas Juan". 
Margarita López Fernández de Heredia a María Rita Ximénez de Urrea, Zaragoza 5 de octubre de 1763:

"Par(ien)ta. Amiga, y Q(ueri)da. mia: Recivo tu apreciable Carta con $\mathrm{f}(\mathrm{ec})$ ha. del 24 proximo pasado, participandome buestra determinación en el acomodo de tu amada Hija, con el S(eño)r. D(o)n. Fran(cis)co. Soler de Cornellá, apruebole, y me congratulo, por tener largas, y buenas noticias de este Cavallero, y su Familia, siendo igualm(en)te. apetecibles, y de Noble calidad; no puedo dejar de darte las mas expresibas enhorabuenas, deseando $\mathrm{q}(\mathrm{u}) \mathrm{e}$. este desposorio se efectue con el gusto, rcgocijo, y alegria, q(u)e. corresponde en semejantes casos, y q(u)e. su Divina Mag(esta)d. los mantenga tan buenos, como mi cariño desea; Maria Ang(e)la. lo celebra, y te hace la misma expresion, q(u)e. yo abrazandotc ambas de Cor(azo)n. poniendose mi Marido â tus $\mathrm{P}(\mathrm{ie})$ s. y todos b(esan). l(a). m(ano), al P(arien)tc. D(o)n. Nicolas, y demas de Casa como mi Herm(an)o. y Niño, q(u)e. esta Bellisimo; y quedando â tu obed(ienci)a. con todo afecto ruego â Dios te g(uard)e. m(ucho)s. a(ñno)s. como deseo. Zarag(oz)a. 5 Oct(ubr)e. de 1763.

$\mathrm{P}($ arien)ta. Am(ig)a. y q(ueri)da. sea mil vezes enorabuena el agustado casam(ien)to. de tu Hixa M(ari)a. Rafaela, con D(o)n. fr(ancis)co. Soler de Cornellâ en quien concurren circunstancias tan apreciables, y desseamos assi M(ari)a. Angela, como yo mi H(erman)o. y mi Marido, el que se susigan las mayores lelicidades à entrambos como se merezen y que tu y el $\mathrm{P}($ arien)te. $S($ ñno)r. $\mathrm{D}(\mathrm{o})$ n. Nicolas tengais la satisfacion, y consuclo de ver a buestras amables Hixas e Hixo, tanbicn colocadas como se merezen, y nuestro fino cariño, y verdadera amistad anela. dala a la Novia mil parabienas de parte de todos repitiendoos milenorabuenas y a m(ari)a. fr(ancis)ca. y su marido que celebraremos esten con s(alu)d. y que d(io)s. les de sucesion ya que se les llevo el Niño. mi Nieto está vellisimo y robusto se parece a tus $\mathrm{P}$ (adre)s. como su P(adr)e. abrazandote de corazon su M(adr)e. y no te escrive la enorabuena porque csta todavia algo delicada de el Mal parto que tubo dias pasados de dos Messes y sietc dias pero gracias a d(io)s. a sido con felicidad en recobro y todavia no se conocia; y assi esta carta va de parte de las dos por no cansarte mas desseando estes aliviada de la destenplanza de caveza, y quedo para servirte siempre, de corazon.

te B.L.M. tu p(arien)ta. Am(ig)a. y fina serv(ido)ra.

Marg(ari)ta. Lopez frern(ande)z. de Eredia

Par(ien)ta. y Q(ueri)da. mia D(oñ)a. Maria Rita Xim(ene)z. de Urrea". 
El Marqués de Lazán a Nicolás Juan, Valencia 5 de octubre de 1763:

"Val(enci)a. y Oct(ub)re. 5 de 1763

Muy señor mío y mi Primo: en carta de 23 del pasado me participa Vs. el combenido Matrimonio de mi Sra. D(oñ)a. M(arí)a. Raphaela, hija de Vs., con el Sr. D(o)n. Fran(cis)co. Soler de Cornella, de q(u)e. doy à Vs. la enorabuena; como tambien à la Parienta, mi Sra. $\mathrm{D}$ (oñ)a. M(arí)a. Rita, cuyas honras estimo, y à cuyos pies quedo; y mi hijo el Marques de Cañizar à la ob(edienci)a. de Vs., estimando su memoria. Dios g(uard)e. à Vs. m(ucho)s. a(ño)s.

\author{
B.L.M. de Vs. su P(rim)o. y Seg(ur)o. serb(ido)r. \\ El Marqués de Lazán \\ Sr. D(o)n. Nicolas Juan".
}

Mariana Pignatelli a María Rita Ximénez de Urrea, Ayerbe 6 de octubre de 1763:

“Ayerbe 6 de 8 bre de 1763

Prima Amiga, y Querida mía: recivo la tuya con mucho gusto, ya por ver disfrutas perfecta salud, ya tambien por la buena noticia, que me das de la proxima colocacion de tu Hija que celebro mucho, y mas siendo el sugeto de las prendas que me dices, las que parece no dan lugar â otro que al contento, que no dudo tendras, y en que te acompaño. Yo lo paso muy bien en este retiro, para servirtc. La Niña se ofrece tuya, y io quedo esperando tus ord(ene)s. y rog(an)do. à Dios te g(uar)de. mu(cho)s. año)s.

Querida prima, selebro infinito y te repito la henorabuena, del casamiento de tu hija y ofresco a tus pies el asenso de mi chico que le an dado bandera en su misma compañia y marcha luego a Barcelona, la chica se ofrece luya quedando yo para serbirte;

te B.L.M. tu Prima y fina serbidora,

Mariana Piñateli

Prima y Q(uerid)a. mia D(oñ)a. Rita Ximenez de Urrea". 
María Margarita Marín y López a María Rita Ximénez de Urrea, Valencia 10 de octubre de 1763:

"P(arien)ta. Amiga y $\mathrm{Q}($ ueri)da. mia recivi tu favorecida carta, bien que atrasada, por allarme fuera, por cuio motibo no te respondi con la puntualidad $q(u)$ e. devia, haora lo executo con mucho gusto, dandote muchas enorabuenas, del ajustado casam(ien)to. de tu Hija M(arí)a. Rafaela, con el S(eño)r. D(o)n. Fran(cis)co. Soler y Cornellâ, y te estimaré la des un abrazo de mi parte, y la henorabuena, y q(u)e. no la escrivo aparte para no duplicar cartas.

El Tio, y Pepe, se ofrecen a tus P(ie)s. y a los de M(arí)a. Rafaela, y os repiten la henorabuena como al $\mathrm{P}(\operatorname{arien})$ te. $\mathrm{S}(\mathrm{eño}) \mathrm{r}$. $\mathrm{D}(\mathrm{o}) \mathrm{n}$. Nicolas, y te cstimaremos nos pongas a su obe(dienci)a.

Zelebrarê $q(u)$ e. estes recobrada de tu indisposicion, y manda pues sabes soi tuya de cor(azo)n. con el q(u)e. ruego a N(uestr)o. S(eño)r. te g(uard)e. m(ucho)s. a(ño)s. Val(enci)a. y 8 bre 10 de 1763/.

te B.L.M. tu P(arien)ta. Am(ig)a. y fina serv(idor)a.

M(arí)a. Margarita Marin, y Lopez

My P(arien)ta. Am(ig)a. y S(eñor)a. D(oñ)a. Rita Jimenes de Urrea".

\section{8}

Josepha de Urries a María Rita Ximénez de Urrea, Zaragoza 11 de octubre de 1763:

"Prima y Q(ueri)da. mia de mi bida recibo la tuia celebrando te alles tan buena y con el gusto de aber pedido à tu ija Maria Rafaela: $\mathrm{D}(\mathrm{o}) \mathrm{n}$. francisco Cornellá que no dudo tendra todas las circunstancias que merece mi sobrina si logra tu aprobacion no quedandome ami otra cosa que la de selebrar todas tus satisfaciones y darte muchas enorabuenas.

el Marques se pone a tus pies y lo celebra ygual mente y à mi primo le daras mis memorias: y no se por que dizes te he olbidado pues sienpre que me as escrito te erespondido y con la diferencia de ser sienpre de mi mano y ati nunca te faltan escusas para azerlo de la ajena pero yo no me formalizo ni me pico de estas cosas pues como sienpre nos emos tratado sin paturatas (i) no miro sino a saber si estas buena y los de tu casa que os deseo á todos muchas felicidades sino que tu eres una quejona biziosa y que te tengo mal acostumbrada con mis bicios y asi trata de enmendar- 
te y manda à tu Prima mientras ruego á Dios te g(uar)de. como deseo Zaragoza y octubre 11 de 1763

por que se te as de alegrar por si acaso no bes la gazeta te digo an echo Alferez de guardias ami sobrino Perico Urries

te B.L.M. tu prima de corazon

Josepha de Urries

mi Prima y S(eño)ra. D(oñ)a. Maria Rita de Urrea".

\section{NOTAS}

1.- Resulta empeño difícil tratar de enumerar todos los estudios publicados. Como relerencias valgan los de Dubert García, I.: Los comportamientos de la familia urbana en la Galicia del Antiguo Régimen. El ejemplo de Santiago de Compostela en el siglo XVIII, Santiago de Compostela, 1987; VV. AA.: La fanilia en la España mediterránea, Barcelona, 1987; Bermejo Barrera, J.C.: Parentesco, familia y matrimonio en la historia de Galicia, Santiago de Compostela, 1988; Reher, D.S.: Familia, población y sociedad en la provincia de Cuenca, 1700-1970, Madrid, 1988; Hemández Bermejo, M.A.: La familia extremeña en los tiempos modernos, Badajoz, 1990; Chacón Giménez, F. (Ed.): Historia social de la familia en España, Alicante, 1990; Barrera González, A.: Casa, herencia y familia en la Cataluña rural, Madrid, 1990; Chacón Giménez, F. y Hernández Franco, J. (Eds.): Poder, familia y consanguinidad en la España del Antiguo Régimen, Barcelona, 1992; Chacón, F., Hernández Franco, J., Peñafiel Ramón, A.: Fcunilica, grupos sociales y mujer en España (ss. XV-XIX), Murcia, 1991; Montojo Montojo, V. (Ed.): Linaje, familia y marginación en España (ss. XII-XIX), Murcia, 1992; Duberl García, I.: Historia de la familia en Galicia durante la época modema, 1550-1830, Santiago de Compostcla, 1992.

2.- Chacón, F.: "La familia española: una historia por hacer", en La familia en la España mediterránea (ss. XV-XIX), Barcelona, 1987; el mismo artículo en Historia social de la familia en España, Instituto "Juan Gil-Albert", Alicante, 1990.

3.- Atienza Hernández, I.: "Teoría y administración de la casa, linaje, familia extensa, ciclo vital y aristocracia en Castilla (ss. XVI-XIX)", en Chacón, F., Hernández Franco, J. y Peñafiel Ramón, A. (Eds.): Familia, grupos sociales y mujer en España (ss. XV-XIX), Murcia, 1991, pp. 14-15.

4.- Valgan como ejemplo los estudios de Torras i Ribé, J.M.: Evolució social i econòmica d'una fanilia catalana de l'Antic Règim. Els Padró d'Igualada (1642-1862), Barcelona, 1976; Fernández, R.: "La burguesía barcelonesa en el siglo XVIII: la familia Gloria", en La Economía española al final del Antiguo Régimen. II.- Manufacturas, Madrid, 1982; Bencomo Mora, C.: "La familia Milans. Comercio y nobleza en la Cataluña del siglo XVIII", en Pedralbes, n 3 (1983), pp. 327-331; Planes i Closa, J.M.: "Radiografía d'un 
municipi borbònic català: Persones i grups socials a Tàrrega, 1715-1750", cn Manuscrits, $n^{\circ} 6$ (1987), pp. 151-179; Mateo Ripoll, V.: La familia Bourgunyo: estudio de una élite urbana alicantina en el siglo XVIII, Memoria de Licenciatura inćdita. Facultad de Filosofía y Letras. Alicante, 1991.

5 - Bernabé Gil, D.: Monarquía y patriciado urbano en Orihuela, 1445-1707, Alicante, 1990; del mismo autor "La insaculación como instrumento de reproducción social y familiar de una élite de poder urbano. La clase dirigente oriolana entrc 1445 y 1705 ", cn Chacón, F. y otros (Eds.): Fanilia, grupos sociales y mujer ..., pp. 95-115.

6.- Benítez Sánchez-Blanco, R.: "Familia y transmisión de la propiedad en el País Valenciano (siglos XVI-XVII). Ponderación global y marco jurídico", en Chacón Jiménez, F. y Hernández Franco, J. (Eds.): Poder, familia y consanguinidad ..., pp. 35-70; Matalí Vidal, R.V.: "Herencia y matrimonio en la Valencia del Seiscientos: Familia y aproximación a la siuación de la mujer", en Chacón, F. y otros (Eds.): Familia, grupos sociales y mujer $\ldots$, pp. $151-178$.

7.- Para los aspectos referidos a la nobleza resulta imprescindible, hoy por hoy y a falta de estudios de índole general, la consulta de Domínguez Ortiz, A.: Las clases privilegiadas en la España del Antiguo Régimen, Madrid, 1973. No obstante disponemos de excelentes estudios monográlicos sobre patrimonios nobiliarios concretos como son los de Serra $i$ Puig, E.: "Evolució d'un patrimoni nobiliari català durant els segles XVII i XVIII. El patrimoni nobiliari dels Sentmenat", en Recerques, $n^{\circ} 5$ (1975), pp. 33-71; Atienza Hernández, l.: Aristocracia, poder y riqueza en la España modema. La Casa de Osuna, siglo XV-XIX, Madrid, 1987; Aragón Mateos, S.: La nobleza extremeña en el siglo XVIII, Mérida, 1990.

8.- Archivo de la Marquesa del Bosch (en adelante AMB), legajo 253. Desde cstas líneas queremos agradecer todas las facilidades dadas para la consulta de su archivo lamiliar a $D^{a}$ María Teresa de Rojas y Roca de Togores y a su esposo D. Alfonso de Borbón y Caralt.

9.- Para aspectos concretos relativos a las diferentes categorias nobiliarias valencianas ver Madramany Calatayud, M.: Tratado de la nobleza de la Corona de Aragón especialmente del Reino de Valencia comparada con la de Castilla. Para ilustración de la Real Cedula del Señor Don Lais I de 14 de agosto de 1724. En Valencia por Josef y Tomás de Orga, año MDCCLXXXVIII.

10.- Ver. Chacón Jiménez, F.: Historia social de la familia ...; igualmente Matco Ripoll, V. La familia Bourgunyo. Estudio de una elite ....

11.- Aunque parezca Irívolo el empleo del símil, la palabra "función" en referencia a la ceremonia de la boda no es nuestra. El propio Francisco Soler emplea este término en varias de sus cartas.

12.- Archivo Parroquial de San Nicolás de Alicante (APSNA). Libro de Desposados, 17631770 , fol. 19 vio.

13.- Miembro de este linaje lue el noble Don Gaspar Soler Chacón. Relcrencias a su ligura se hallan en el trabajo de Serrano Jaén, J.: "Un noble il.licità del segle XVII: Gaspar Soler i Chacon (1592-1629)", en Festa d'Elx, núm. 42, 1990, págs. 39-53. Otro ilusire personaje de esta lamilia ha sido estudiado por Baldaquí, R.: "La reforma de la predicación en los ilustrados valencianos: Leonardo Soler de Cornellá", en Alberola, A. y La Parra, E. (Eds.): La llustración Española. Actas del Coloquio de Alicante. Instituto Juan GilAlbert. Alicante, 1986, pp. 197-206. Del mismo autor "La reforma de la predicación en cl XVIII valenciano: Leonardo Soler de Cornellá", en Anales Valentinos. Revista de 
Filosofía y Teología, año XIII (1987), núm. 25. Págs. 87-137. Este Leonardo era hermano de Francisco Soler de Cornellá, a cuyo matrimonio se dirije nuestro presente trabajo. El estudio en conjunto de la familia Soler de Cornellá, en su aspecto cconómico y político lo tenemos en Baldaquí, R. y Pradells, J.: "La familia de Don Leonardo Soler de Cornellá. Un linaje de caballeros en Elche durante el siglo XVIII". en Revisia de Historia Moderna, núm. 11. (1992). Págs. 25-65. Un reciente estudio de conjunto en Baldaquí Escandell, R.: Els Soler de Cornellà a Elx en el segle XVIII, Elx, 1993.

14. Barón de Fincstrat (Don José Luis de la Guardia y Pascual del Pobil): Nobiliario Alicantino. Instituto de Estudios Alicantinos. Alicante, 1983. Pág. 315.

15.- Cif. Baldaquí, R.: “La reforma...”, y Baldaquí, R. y Pradells, J.: “La familia de Don Leonardo...".

16.- El ingreso en este cuerpo distinguido y estrictamente nobiliario, dentro del Ejército español del XVIII, requería la justificación de una nobleza de mayor rango que la simple hidalguía. Vid. al respecto Andújar Castillo, F.: Los militares en la España del siglo XVIII. Un estudio social. Universidad de Granada, 1991. Págs. 167-168.

17.- Archivo Municipal de Elche (AME). Protocolos Notariales de Francisco Gil de Agulló, año 1763, fols. 17-28. Poder otorgado por don Dionisio Soler de Cornellá en la ciudad de Mérida el 6 de diciembre de 1762, a favor de su lío don Pedro Ortiz de Rodrigo y Soler, ante el escribano Francisco González Calderón, cuya copia legalizada se halla incluída en dicho protocolo.

18.- Sobre su matrimonio vid. Barón de Finestrat: Nobiliario ..., pág. 315.

19.- El marino y cientílico Jorge Juan Santacilia, primo segundo de los hermanos Soler de Cornellá cra también caballero de la Orden de San Juan de Jerusalén. Esta prestigiosa institución del XVIII europeo era tremendamente exigente en cuanto a sus pruebas de acceso y muy rigurosa en lo referente al celibato. Ver Aragón Mateos, S.: La nobleza extremeña..., pág. 455.

20.- AME, Protocolos Notariales de Francisco Gil de Agulló, año 1763, fol. 38.

21.- Barón de Finestrat: Nobiliario ..., pág. 315.

22.- Baldaquí, R. y Pradells, J.: La familia de don Leonardo..., pág. 29.

23.- Barón de Finestral: Nobiliario ..., págs. 20 y 158.

24.- El barón de Finestrat, en su Nobiliario... no recoge el nacimiento de Antonia. Ignoramos la fecha y el lugar en que se produjo, pero entre las cartas recibidas por Nicolás Juan con motivo de la boda de su hija, se encuentra una de Antonia Yvarra, fechada en Elche el 27 de septiembre de 1763. Asi mismo, en los autos de declaración de herederos abintestato, seguidos en 1773 a la muerte de Jorge Juan, se nombra a Antonia como una de las hijas habidas del primer matrimonio de Violante Santacilia con Pedro Ybarra. Ver Navarro Mallebrera, R. y Navarro Escolano, A.M.: "La biblioteca de Jorge Juan", Alicante, 1987. Pág. 120.

25.- Respecto a las distintas clases de parentesco ver Castán Tobeñas, J.: Derecho Civil Español, Común y Foral. Madrid, 1949 (Séptima Edición). Tomo Primero, pág. 433.

26.- Aunque el barón de Finestrat en su Nobiliario..., fol. 159, cita únicamente a dos hijas, llamadas María Manuela e Isabel María, nosotros hemos encontrado referencias documentales de tres: María Antonia, María Manuela c Isabel María. Es posible, incluso, que existiera una cuarta llamada María Teresa. El nombre de ésta última se recoge en el borrador escrito por el propio Nicolás con la lista de personas a quienes debía comunicar la boda 
de Rafaela, donde se menciona a "mi H(ij)a. María Theresa...";AMB, Legajo 253. De María Antonia podemos decir que era religiosa profesa de San Agustín en el Convento de la Sangre de Cristo en Alicante. En abril de 1765 Nicolás Juan, como padre y administrador de los bienes de su hija sor María Antonia Juan Yvarra otorga un poder notarial a favor de un procurador de Valencia; Archivo Histórico Provincial de Alicante (AHPA), Protocolos Notariales de Bartolomé Calatayud 1761-1768, P/371, Col. 98. A María Manuela, casada con Juan Roca de Togores, alude Francisco Soler en una de sus cartas; AMB. Francisco Soler a Nicolás Juan, Elche 6-8-1763. Finalmente de Isabel María hemos de corregir y ampliar los datos recogidos por el barón de Finestrat puesto que contrajo matrimonio con Salvador de Medina y Jorge en Orihuela el 22 de febrero de 1754, siendo el 10 de septiembre de dicho año en Alicante cuando recibicron las bendiciones nupciales; APSNA, Libro de desposados, año 1754, fol. 146 vto. En diciembre de 1755 Isabel ya había fallecido, dejando dos hijos llamados María Teresa y Salvador. Aunque en la Iglesia de San Nicolás no se conservan los libros de defunciones, conocemos este dato porque el 27 de diciembre de 1755 don Salvador de Medina, como padre y administrador de sus dos hijos, declara haber recibido de don Nicolás Juan 108 pesos para satisfacer cl funeral de su esposa, otorgándole carta de pago de la citadá cantidad; AHPA. Protocolos de Melchor Aracil. Año 1755. P/105, fols. 183-184.

27.- Barón de Finestrat: Nobiliario..., pág. 159.

28.- AME. Protocolos Notariales de Diego Mira, año 1740.

29.- AME, Protocolos Notariales de Carlos Pasqual, año 1757, ff. 50vto-56vto.

30.- Aunque no se especifica la extensión de dicha heredad creemos que debía abarcar alrededor de 596 tahúllas, que son las que poseía Don Pedro en Asprillas tal y como indica Gozálvez Pérez, V.: El Bajo Vinalopó. Geografía agraria. Valencia, 1977, pág. 158.

31. En el testamento de Francisco Soler, efectuado el 11 de enero de 1796, éste declara que la tierra situada en Beniay no llegó nunca a su poder pues fue vendida por su tío don Pedro, años antes de morir, a don Félix Desplá. AME. Protocolos notariales de Francisco Gil de Agulló, año 1796, fol. 35 vto.

32.- Baldaquí, R. y Pradells, J.: "La familia de don Leonardo...", pág. 34 y nota 72 en pág. 56.

33.- AME. Protocolos Notariales de Francisco Gil de Agullo, año 1796.

34.- AME. Protocolos Notariales de Francisco Gil de Agulló, 1763. Fol. 38 vio.

35.- AME. Protocolos notariales de Francisco Gil de Agullo, 1763, fols. 29-37 vto. En estc protocolo se contienen los originales de las diligencias judiciales de justiprecio instadas por don Leonardo, en septiembre de 1762.

36.- AME. Protocolos Notariales de Francisco Gil de Agulló, año 1762, fols. 88-89 vto. Contiene el codicilo otorgado por don Leonardo el 20 de octubre de ese año.

37.- Bernardo Juan Santacilia, designado por el testador para proceder extrajudicialmente al inventario, tasación y partición de la herencia, hubo de estudiar para ello determinadas escrituras y disposiciones que regulaban el reparto de los bienes según la procedencia de éstos. Así, le fue preciso analizar la escritura de constitución dotal y cartas matrimoniales suscrita entre don Leonardo Soler y doña Vicenta Ros el 23 de noviembre de 1724, ante cl escribano de Onteniente Pascual Calatayud; el testamento de dichos cónyuges en Elche el 25 de marzo de 1740, ante Diego Mira; los codicilos otorgados por don Leonardo en Elche los días 8 y 10 de abril de 1751 ante Juan Gil, y el 20 de octubre de 1762 ante Francisco Gil de Agulló; la escritura de transacción y concordia, división y partición de 
la herencia de doña Lucía Anna Barberá Despuch, madre de doña Vicenta Ros, otorgada por sus herederos ante el escribano de Onteniente Pascual Calatayud el 13 de marzo de 1743; la donación a lítulo de órdenes efectuada por don Leonardo a favor de su hijo Leonardo, ante el notario de Elche Carlos Pascual, el 17 de marzo de 1753; y, finalmente, las diligencias de justiprecio de determinados bienes, instadas por el difunto don Leonardo en septiembre de 1762 ante el Corregidor de Onteniente. AME. Protocolos notariales de Francisco Gil de Agulló, año 1763, fols. 38-67.

38. AME. Ibidem. Antes de esta escritura, pero formando parte del cuaderno particional, se incluyen dos distintos documentos, a saber: en los folios 17 a 28 un poder otorgado en la ciudad de Mérida por Dionisio Soler en fecha 6 de diciembre de 1762, a favor de don Pedro Ortiz de Rodrigo y Soler, para que pudiera intervenir en su nombre en las operaciones sucesorias; los folios 29 a 37 vto. corresponden a los autos de justiprecio de determinadas fincas, instados por el difunto Leonardo Soler de Cornellá ante el corregidor de la villa de Onteniente en fecha 9 de octubre de 1762.

39. - La herencia de doña Lucía Anna Barberá provocó muchas disputas y diferencias entre don Leonardo Soler, como padre y administrador de los bienes de sus hijos, y el resto de los herederos de la fallecida. Finalmente, el 13 de marzo de 1743, se llegó a un acuerdo entre todos, otorgándose una escritura de transacción, concordia, división y partición ante el escrivano de Onteniente Pascual Calatayud. AME. Protocolos Notariales de Francisco Gil de Agulló, año 1763. Fol. 40 vto.

40.- AME. Protocolos Notariales de Francisco Gil de Agulló, año 1793. Dichas propiedades, cuyo justiprecio instó junto con otras don Leonardo en octubre de 1762 ante el Justicia de la villa de Onteniente, eran las siguientes:

- Una casa mesón, sita en la plaza principal de Onteniente, titulada el mesón de la plaza. Sc valoró por los peritos en 1.127 libras.

- Otra casa sita en la misma plaza, lindante con dicho mesón. Valorada en 423 libras.

- Dos casitas o medianos sitas en el callizo de San Miguel, por cuamía cada una de 67 libras, en total 134 libras.

- Un molino harinero de una muela, titulado de San Jaime, con un huertecito ancjo sito en el barranco de San Jaime. Valorado en 1.025 libras.

- Otra casa con su mediano sita en la bajada de la luente de San Jaime. La casa se tasó en 118 libras y el mediano en 67 libras, todo lo cual sumaba 185 libras.

41.- AMB. Francisco Soler a Nicolás Juan, Elche 16-4-1763.

42.- AMB. Francisco Soler a Nicolás Juan, Elche 6-8-1763. Respecto a la cuantía de la pensión conviene señalar que, habiéndose fijado en la cilra de 189 libras, csta cantidad es notablemente inferior a la que consta en la escritura de división y partición de herencia electuada en 1796, a la muerte de Francisco, donde se declara que dicha pensión de viudedad ascendía a la cantidad de 442 pesos. (AME., Protocolos de Francisco Gil de Agulló, 1796 , lol. 54 vto.). Esta discrepancia es debida al hecho de que la pensión se lijaba atendiendo a la cuantía de las rentas que producian los bienes vinculados. En 1763 Francisco Solcr únicamente había heredado el vínculo instituído por sus padres. Con posterioridad llegó a heredar hasta tres vínculos más, por lo que debió solicitar ampliaciones de la pensión de viudedad conforme aumentaban sus rentas.

43.- Se trata de una de las hijas habidas del primer matrimonio de Nicolás Juan con Teresa Ybarra Santacilia. Manuela había contraído matrimonio en 1750 con Juan Roca de Togores. Vid. Barón de Finestrat: Nobiliario... pág. 252. 
44.- AMB. Francisco Soler a Jorge Juan, sin fecha, pero anterior al 3-9-1763., según se infiere de la carta de Jorge Juan a su hermano Nicolás fechada en tal día.

45.- AMB. Francisco Soler a Nicolás Juan, Elche 11-6-1763.

46.- AMB. Francisco Soler a Nicolás Juan, Elche 20-8-1763.

47.- AMB. Francisco Soler a Jorge Juan. Sin fecha pero anterior al 3 de septiembre.

48.- AMB. Jorge Juan a Nicolás Juan, Madrid 3-9-1763.

49.- AMB. Copia, Nicolás Juan a Jorge Juan, Alicante 7-9-1763.

50.- AMB. Francisco Soler a Nicolás Juan, Elche 10-9.1763.

51.- AMB. Francisco Soler a Nicolás Juan, Elche 13-9-1763.

52.- AMB. Maria Rafaela Juan a Francisco Soler, borrador sin fecha escrito en la parte posterior del borrador de la carta de María Rafaela Juan a Joseph de Puigmoltó, fechado en Alicante el 22 de septiembre de 1763.

53.- AME. Protocolos Notariales de Francisco Gil de Agulló, año 1763. Fols. 38-67.

54.- AME. Protocolos Notariales de Francisco Gil de Agulló, año 1762. Fol, 89.

55.- AMB. Despacho de la Administracion de Rentas Generales a cuenta de la Real. Hacienda, Valencia 22-10-1763.

56.- AMB. Francisco Soler a Rafaela Juan, Valencia 18-10-1763.

57.- Joseph Townsend: Viaje por España en la época de Carlos III (1786-1787). Ed. Turner, Madrid 1988. Págs. 388-391.

58.- Giménez López, E.: Alicante en el siglo XVIII. Economía de una ciudad portuaria en el Antiguo Régimen. Valencia, 1981. Págs. 31-32.

59.- Sobre la velocidad media que alcanzaba el transporte de la época por carretera ver también Mas Galvañ, C.: "Artesanía, Manufacturas y Actividades comerciales" en: Mestre Sanchis, A. (Dir.) Historia de la Provincia de Alicante, T.IV, Murcia 1985, pág. 165.

60.- AMB. Francisco Soler a Nicolás Juan, Elche 29-10-1763.

61.- AMB. Bernardo Juan a Maria Rita Ximénez de Urrea, Elche 29-10-1763.

62.- AMB. Francisco Soler a Nicolás Juan, Elche 19-11-1763.

63.- Barón de Finestrat: Nobiliario...,pág. 158.

64.- AMB. Bernardo Juan a María Rita Ximénez de Urrea, Elche 25-10-1763.

65.- AMB. Bernardo Juan a Maria Rita Ximénez de Urrea, Elche 29-10-1763".

66.- Ramón Baldaquí, analizando el mobiliario de la casa de los Soler de Cornellá, otorga este carácter al salón donde se encontrarían los muebles más lujosos; Baldaquí Escandell, R.: Els Soler de Comellá a Elx..., pág. 19 y nota 105. Sobre el estrado en general ver también Martín Gaite, C.: Usos amorosos del dieciocho en España. Barcelona, 1987. Págs. 27-28.

67.- AMB. Francisco Soler a Nicolás Juan, Elche 29-10-1763.

68.- Aragón Mateos, S.: La nobleza extremeña..., pág. 162.

69.- AMB. Francisco Soler a Nicolás Juan, Elche 19-11-1763.

70.- AME. Protocolos notariales de Francisco Gil de Agulló, año 1796. Fols. 34 vto-38 vto. y 375-392. Además de las 4.172 libras de sus legítimas paterna y materna, Rafaela hercdó también las siguientes cantidades: 
- 1.483 libras cobradas en 8 años por el legado pío de Agustín que le adjudicaron los administradores de la Iglesia Metropolitana de Zaragoza.

- 2.400 libras que le correspondieron por su quinta parte proindivisa en las 30 cahizadas de tierra sitas en término de Luseni y Berbedel en Zaragoza.

- 190 libras 9 sueldos 6 dineros de la herencia de su hermana sor Maria Antonia Juan, religiosa en el Convento de la Sangre en Alicante.

- 82 libras que le tocaron en la herencia de su tio Cipriano Juan.

- 559 libras que le correspondieron de su séptima parte en la heredad de Castillo que se vendió.

71.- AMB. Pedro Albornoz Tapies, obispo de Orihuela, a Nicolás Juan. Orihuela, 19-111763.

72.- AMB. Francisco Soler a Nicolás Juan, Elche 19-11-1763.

73.- AMB. Francisco Soler a Nicolás Juan, Elche 9-12-1763.

74.- APSNA. Libro de Desposados 1763-1770, fol. 19vto.

75.- AMB. Francisco Soler a Jorge Juan, sin fecha pero anterior al 3 de septiembre.

76.- Sanz, M.: Breve Noticia de la vida del Excmo. Sr. D. Jorge Juan y Sanacilia (...), presenta al Público su secretario —_. Oficial Segundo de la Contaduria Principal de Marina. Impreso sin pie de imprenta ni fecha. En esta obra se explica que, debido a sus ya conocidos problemas de salud, Jorge Juan interrumpió sus ocupaciones para trasladarse a Alicante. Emprendió viaje el 25 de noviembre y permaneció en esta ciudad hasta ef 31 de mayo de 1764 . Es interesante señalar que tan oportuna recaída en sus quebrantos posibilitó su asistencia tanto a la boda de Francisco Soler con su sobrina Ralacla Juan, como a la de su propio hermano Bernardo Juan, quien contrajo matrimonio con Luisa Pasqual de Bonanza en abril de 1764.

77.- AMB. Francisco Soler a Nicolás Juan, Elche 9-12-1763.

78.- AMB. Francisco Soler a Nicolás Juan, Elche 9-12-1763.

79.- AMB. Francisco Soler a Nicolás Juan, Elche 10-12-1763.

80.- APSNA. Libro de Desposados 1763-1770, 1ol. 19vto.

81.- Vid. Apéndice Documental número 28. Borrador escrito por Nicolás Juan.

82.- AMB. Miguel (ilegible) a Nicolás Juan, Zaragoza 5-10-1763.

83.- AMB. Margaria López Fernández de Heredia a Maria Rita Ximénez de Urrea, Zaragoza 5-10-1763.

84.- AMB. Mariana Pignatelli a Maria Rita Ximénez de Urrea, Ayerbe 6-10-1763.

85.- AMB. Joseph Marin y Gurrea a Nicolás Juan, Zaragoza 5-10-1763.

86.- AMB. Isidoro a Nicolás. Juan, Cartagena 21-9-1763.

87.- AMB. Margarita López a María Rita Ximénez de Urrea, Zaragoza 5-10-1763.

88.- AMB. Mariana Pignatelli a María Rita Ximénez de Urrea, Ayerbe 6-10-1763.

89.- AMB.Josepha de Urries a Maria Rita Ximénez de Urrea, Zaragoza 11-10-1763.

90.- AMB. Josepha de Urries a María Rita Ximénez de Urrea, Zaragoza 11-10-1763.

91.- AMB. El marqués de Arneba a Nicolás Juan, Orihuela 20-9-1763.

92.- AMB. Margarita López a María Rita Ximénez de Urrea, Zaragoza 5-10-1763. 
93.- AMB. Francisco Soler a Nicolás Juan, Elche 17-9-1763.

94.- AMB. Francisco Soler a Rafaela Juan, Elche 17-9-1763.

95.- AMB. Francisco Soler a Rafaela Juan, Valencia 18-10-1763.

96.- AMB. Borrador de una carta escrita de puño y letra de Nicolás Juan pero dirigida por Rafaela Juan a Francisco Soler, sin fechar. Está escrito por el veverso de otro borrador dirigido por Rafaela Juan a Joseph de Puigmoltó, Alicante 22-9-1763. 